\title{
Assessment of plankton community and environmental conditions in São Sebastião Channel prior to the construction of a produced water outfall
}

\author{
Sônia Maria Flores Gianesella, Miryam Bertha Burda Kutner, Flávia Marisa \\ Prado Saldanha-Corrêa \& Mayza Pompeu
}

Instituto Oceanográfico da Universidade de São Paulo

(Caixa Postal 66149, 05315-970 São Paulo, SP, Brasil)

- Abstract: Plankton community and hydrological conditions were assessed as a part of an environmental diagnosis in São Sebastião Channel, before the building of a submarine outfall of produced water from the oil maritime terminal of PETROBRÁS. Samples were collected in twenty oceanographic stations located in the oil terminal neighboring area, during the springtime of 1991. Dissolved inorganic nutrients and chlorophyll- $a$ concentrations observed indicate an oligo-mesotrophic environment. Phenols and sulfides were absent, BOD values, except for three sampling points, were characteristic of unpolluted environments, although oil and grease were found in half of the sampled stations. Phytoplankton and zooplankton communities presented high diversity and evenness indices for the entire area. Phytoplankton was dominated by phytoflagellates and zooplankton was dominated by copepods, mostly Paracalanus quasimodo. Plankton community composition was similar to that from adjacent regions under low anthropogenic influence.

- Resumo: A comunidade planctônica e condições hidrológicas foram avaliadas como parte de um diagnóstico ambiental no Canal de São Sebastião, previamente à construção de um emissário submarino de água de produção, oriunda do terminal marítimo da PETROBRÁS. As amostras foram coletadas em vinte estações oceanográficas situadas na área adjacente ao terminal petrolífero, durante a primavera de 1991. As concentrações de nutrientes inorgânicos dissolvidos e de clorofila- $a$ obtidas, indicam um ambiente oligo-mesotrófico. Fenóis e sulfetos não foram detectados e os valores de DBO, com exceção de três pontos, foram característicos de ambientes não poluídos, apesar da contaminação por óleos e graxas ter sido observada em metade das estações amostradas. O fito e o zooplâncton apresentaram altos índices de diversidade e equitatividade para toda área estudada. O fitoplâncton foi dominado por fitoflagelados, enquanto que o zooplâncton foi dominado por copépodos, especialmente Paracalanus quasimodo. A composição da comunidade planctônica foi similar à de outras áreas adjacentes, sob baixa pressão antropogênica.

- Descriptors: Phytoplankton, Zooplankton, Nutrients, Suspended matter, BOD, Oil and grease, Environmental diagnosis, São Sebastião Channel.

- Descritores: Fitoplâncton, Zooplâncton, Nutrientes, Material em suspensão, DBO, Óleos e graxas, Diagnóstico ambiental, Canal de São Sebastião. 


\section{Introduction}

The environmental diagnosis for the assessment of anthropogenic impacts is a general concern and a good evaluation represents a great challenge. Identification of stress indicators has been searched intensively through the last decades. According to Rapport (1992) several characteristics should be considered in the health assessment of an aquatic ecosystem: biotic community structure, species diversity, food chain length and population stability are some examples.

São Sebastião Channel (SSC) and surrounding areas have been submitted to anthropogenic impacts, especially after the building of the São Sebastião Harbor and of the "Duto e Terminais Centro Sul" (DTCS), an oil maritime terminal. DTCS will contribute with another contamination source for SSC waters: an aqueous effluent composed mainly by produced water (a sub-product originated principally in the oilbearing formation). In the early lifetime of an oil field, produced water content is small but it constitutes an increasing fraction of the production stream with time, until it gets too large for economic oil production (Sommerville et al., 1987). During the production process, water and oil become very intimately mixed, and oil droplets and components from the oil and added production chemicals will disperse or dissolve into the production water. This may increase the toxicity of the produced water towards the marine environment (Strфmgren et al., 1995). After discharge into the sea, the produced water will be diluted (depending on local conditions). Evaporation and biodegradation will change the content and composition of its inorganic constituents (Sommerville et al., op. cit.).

The present work was conducted prior to the building of the DTCS submarine produced water outfall, in order to establish a baseline description for future monitoring. Beyond the produced water, the aqueous effluent should contain ballast water, high salinity water (resultant from the crude oil desalting process) and land drainage waters from DTCS area. As a part of this pre-monitoring program, sponsored by PETROBRÁS, other studies were carried out related to the determination of the potential toxicity of this effluent through bioassays using: the diatom Skeletonema costatum (Aidar et al., submitted), the gastropod Costoanachis sertulariarum (Souza \& Tommasi, 1997) and the mysid Promysis atlantica (Phan et al., 1994). All these studies pointed out the high toxicity of the effluent indicating the necessity of a pre-treatment and controlled disposal.

\section{Study area}

São Sebastião Channel (SSC) lies at the Northeast coast of São Paulo State (from $23^{\circ} 41^{\prime} \mathrm{S}$ $45^{\circ} 19^{\prime} \mathrm{W}$ to $23^{\circ} 53^{\prime} \mathrm{S}-45^{\circ} 30^{\prime} \mathrm{W}$ ), delimited by the Serra do Mar slopes and São Sebastião Island (Fig. 1). This funnel shaped channel is curved along its $25 \mathrm{~km}$ extension with the narrowest part $(2 \mathrm{~km}$ wide) in the center, enlarging up to $7.2 \mathrm{~km}$, at the Southern entrance, and $5.6 \mathrm{~km}$ at the Northern one. Along the longitudinal axis, depths range from around $20 \mathrm{~m}$ at the entrances up to $50 \mathrm{~m}$ in the inner portion. The deepest part of this longitudinal axis is closer to the island margin, being called "main axis" or navigation channel (Silva, 1995). High lands surround SSC providing substantial wind protection from the open sea (Furtado, 1978). Such characteristics afford optimal conditions for the establishment of harbor activities. Indeed, SSC shelters the DTCS which is the largest brazilian oil terminal, previously named as "Terminal Almirante Barroso (TEBAR)", in operation since 1967, and also one of the more important brazilian harbors, the São Sebastião Harbor. As a consequence, the channel is frequently exposed to the introduction of small amounts of oil from the routine procedures at DTCS. In addition, several accidental oil spills have occurred in the area. SSC has also been submitted to intense anthropogenic impacts such as coastal land occupation, urban sewage inputs and tourist exploitation. In spite of these vulnerable conditions, few studies have been carried out focusing this area.

The Channel is dominated by Coastal Water (CW) but during spring and summer, a flow of high salinity and low temperature waters (ACAS) can be detected in the deepest layers, mainly close to the Southern entrance which acts as a duct for the South Atlantic Central Water (SACW) penetration. Currents in SSC are predominantly to Northeast and they may be highly variable in space and time. Wind is the main forcing agent on water circulation, while tidal currents have a negligible influence (Castro Filho, 1990). Strong currents (up to 1.4 knots) are a common feature in the main axis and sedimentation processes are more predisposed to occur in the continental margins than in the insular side (Furtado, 1978). Aromatic hydrocarbon contamination was detected in many points along the channel (Weber $\&$ Bícego, 1991): Authors attribute the high variation levels to the oil inputs from both DTCS and oil tankers present in the area during the samplings associated to the surface water circulation. Plankton community of the Southern part of SSC was evaluated by Gaeta et al. (1990) during the autumn. Phytoplankton was largely dominated by 
phytoflagellates followed by diatoms and zooplankton individuals (predominantly copepods) showed a wide range of feeding behavior. The authors pointed out no stress indicators.

\section{Material and methods}

This study was carried out during the austral spring (October 1991) in the neighboring area of the DTCS, surveyed through the samplings in twenty stations (transects A, B, C and D, Fig. 1). Samples were taken once in each station, at three water column levels (surface, mid-water and bottom), according to the station local depth (Table 1). Temperature measurements were obtained "in situ" using reversing thermometers and underwater light penetration was estimated through Secchi disk readings. Euphotic zone thickness $\left(Z_{\text {eu }}\right)$ was computed following the equation given by Poole \& Atkins (1929).
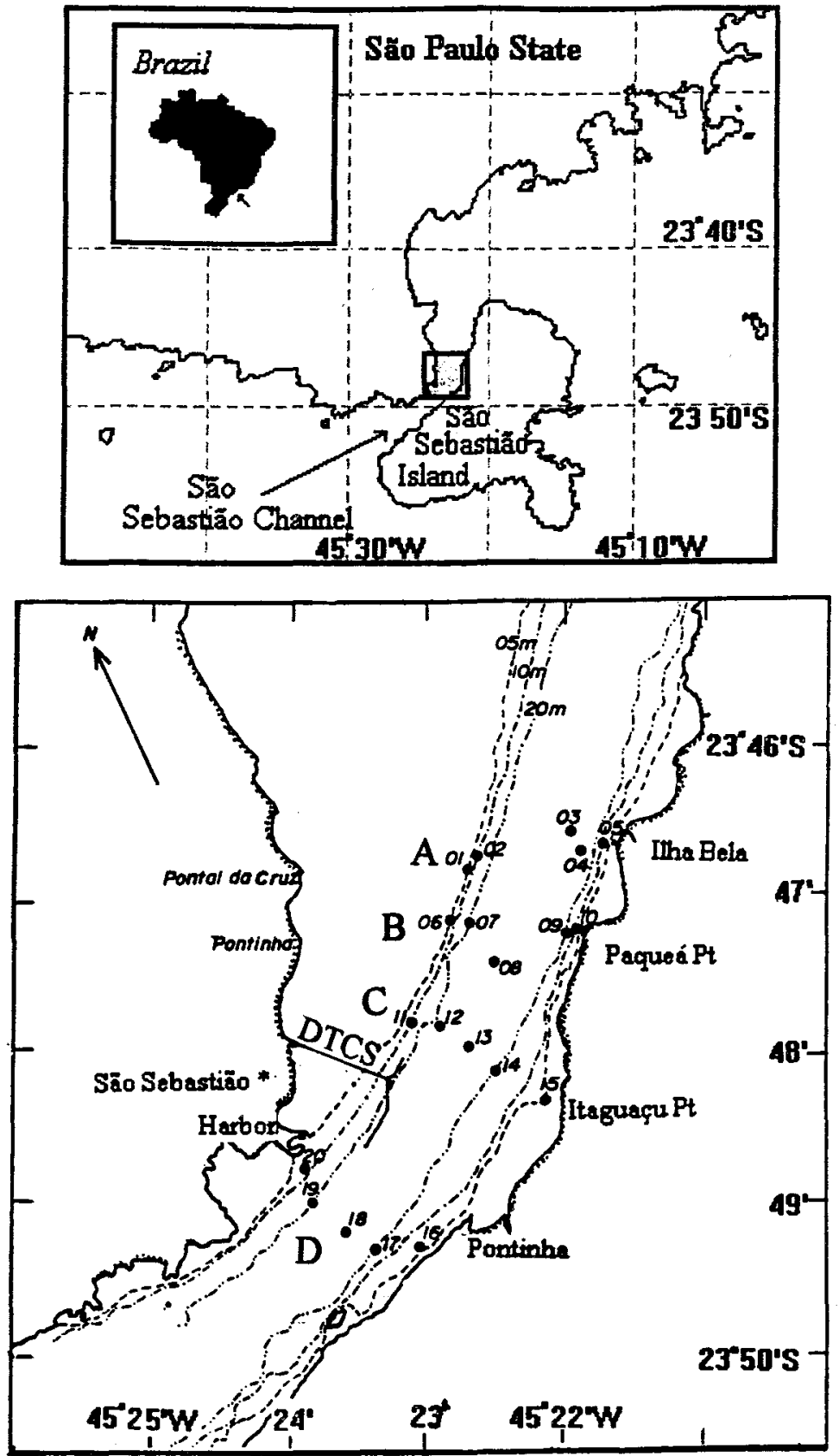

Fig. 1. São Sebastião Channel, at the Northern coast of São Paulo State, and the position of the 20 oceanographic stations performed at the neighboring area of the DTCS oil terminal. 
Table 1. Data on the 20 oceanographic stations performed at São Sebastião Channel: position, local depth, sampling depths and euphotic zone (Zeu) thickness.

\begin{tabular}{|c|c|c|c|c|c|}
\hline Station & $\begin{array}{l}\text { Lat. } \\
\left({ }^{\circ} \mathrm{S}\right) \\
\end{array}$ & $\begin{array}{l}\text { Long. } \\
\left({ }^{\circ} w\right)\end{array}$ & $\begin{array}{l}\text { Local depth } \\
(\mathrm{m})\end{array}$ & $\begin{array}{l}\text { Sampling } \\
\text { depth }(m)\end{array}$ & $\begin{array}{c}\begin{array}{c}Z \text { eu } \\
(\mathrm{m})\end{array} \\
\end{array}$ \\
\hline \multirow[t]{3}{*}{1} & $2346^{\prime} 48^{\prime \prime}$ & $4522^{\prime} 43^{\prime \prime}$ & 6 & 0 & 10.8 \\
\hline & & & & 2.5 & \\
\hline & & & & 5 & \\
\hline \multirow[t]{2}{*}{2} & $2346^{\prime} 42^{\prime \prime}$ & $4522^{\prime} 36^{\prime \prime}$ & 10 & 0 & 13.5 \\
\hline & & & & 4 & \\
\hline \multirow[t]{3}{*}{3} & $2346^{\prime} 32^{\prime \prime}$ & $4521^{\prime} 54^{\prime \prime}$ & 30 & 0 & 13.5 \\
\hline & & & & 14 & \\
\hline & & & & 28 & \\
\hline \multirow[t]{3}{*}{4} & $2346^{\prime} 42^{\prime \prime}$ & $4521^{\prime} 54^{\prime \prime}$ & 22 & 0 & 10.8 \\
\hline & & & & 10 & \\
\hline & & & & 20 & \\
\hline \multirow[t]{3}{*}{5} & $2346^{\prime} 36^{\prime \prime}$ & $4521^{\prime} 48^{\prime \prime}$ & 10 & 0 & 9.5 \\
\hline & & & & 4.5 & \\
\hline & & & & 9 & \\
\hline \multirow[t]{3}{*}{6} & $2347^{\prime} 06^{\prime \prime}$ & $4522^{\prime} 48^{\prime \prime}$ & 6 & 0 & 8.1 \\
\hline & & & & 2.5 & \\
\hline & & & & 5 & \\
\hline \multirow[t]{3}{*}{7} & $2347^{\prime} 06^{\prime \prime}$ & $4522^{\prime} 42^{\prime \prime}$ & 20 & 0 & 31.0 \\
\hline & & & & 7 & \\
\hline & & & & 14 & \\
\hline \multirow[t]{3}{*}{8} & $2347^{\prime} 30^{\prime \prime}$ & 4522 '34" & 31 & 0 & 30.0 \\
\hline & & & & 15 & \\
\hline & & & & 30 & \\
\hline \multirow[t]{3}{*}{9} & $2347^{\prime} 14^{\prime \prime}$ & $4522^{\prime} 00^{\prime \prime}$ & 15 & 0 & 21.6 \\
\hline & & & & 7 & \\
\hline & & & & 14 & \\
\hline \multirow[t]{3}{*}{10} & $2347^{\prime} 12^{\prime \prime}$ & $4521^{\prime} 54^{\prime \prime}$ & 6 & 0 & 16.2 \\
\hline & & & & 3 & \\
\hline & & & & 6 & \\
\hline \multirow[t]{3}{*}{11} & $2348^{\prime} 18^{\prime \prime}$ & $4522^{\prime} 06^{\prime \prime}$ & 6 & 0 & 24.3 \\
\hline & & & & 2.5 & \\
\hline & & & & 5 & \\
\hline \multirow[t]{3}{*}{12} & $2348^{\prime} 09^{\prime \prime}$ & $4522^{\prime} 30^{\prime \prime}$ & 20 & 0 & 30.0 \\
\hline & & & & 9 & \\
\hline & & & & 18 & \\
\hline \multirow[t]{3}{*}{13} & $2347^{\prime} 57^{\prime \prime}$ & $4522^{\prime} 42^{\prime \prime}$ & 36 & 0 & 13.5 \\
\hline & & & & 17 & \\
\hline & & & & 34 & \\
\hline \multirow[t]{3}{*}{14} & $2347^{\prime} 49^{\prime \prime}$ & $4522^{\prime} 54^{\prime \prime}$ & 21 & 0 & 13.5 \\
\hline & & & & 9 & \\
\hline & & & & 18 & \\
\hline \multirow[t]{3}{*}{15} & $2347^{\prime} 48^{\prime \prime}$ & $4523^{\prime} 07^{\prime \prime}$ & 6 & 0 & 5.4 \\
\hline & & & & 2.5 & \\
\hline & & & & 5 & \\
\hline \multirow[t]{3}{*}{16} & $2349^{\prime} 17^{\prime \prime}$ & $4523^{\prime} 02^{\prime \prime}$ & 7 & 0 & 12.0 \\
\hline & & & & 3 & \\
\hline & & & & 6 & \\
\hline 17 & $2349^{\prime} 18^{\prime \prime}$ & $4523^{\prime} 21^{\prime \prime}$ & 20 & 0 & 10.8 \\
\hline & & & & 9 & \\
\hline & & & & 18 & \\
\hline 18 & $2349^{\prime} 11^{\prime \prime}$ & $4523^{\prime} 37^{\prime \prime}$ & 43 & 0 & 9.5 \\
\hline & & & & 21 & \\
\hline & & & & 42 & \\
\hline 19 & $2349^{\prime} 00^{\prime \prime}$ & $4523^{\prime} 51^{\prime \prime}$ & 20 & 0 & 10.8 \\
\hline & & & & 9 & \\
\hline & & & & 18 & \\
\hline 20 & $2348^{\prime} 46^{\prime \prime}$ & $4523^{\prime} 53^{\prime \prime}$ & 7 & 0 & 6.7 \\
\hline & & & & 3 & \\
\hline & & & & 6 & \\
\hline
\end{tabular}

Salinity was determined from samples collected with Nansen bottles and analyzed by the inductive method. Conductivity ratios were converted to salinity values following UNESCO (1981). Samples for chemical and biological analyses were taken with Van Dorn bottles. Water samples were filtered through GF/F Whatman filters, which were used for phytoplankton pigments and suspended matter determinations. Filtered water was frozen for posterior determination of nitrate, nitrite, ammonium (Aminot \& Chaussepied, 1983), phosphate and silicate (Grasshoff et al., 1983). Total Chlorophyll-a (Chlorophyll- $a+$ Phaeophytin- $a$ ) was determined according to Lorenzen (1967) and suspended matter (total, organic and inorganic fractions) by the gravimetric method (APHA, 1985). Samples for other analyses were taken directly from the bottles. Total oil and grease (partition gravimetric method after solvent extraction), sulfide (iodometric method), phenols (4-aminoantipyrine method) and biochemical oxygen démand (BOD) were determined according to APHA (op. cit.).

Bottle samples for phytoplankton countings (Utermöhl, 1958) were fixed with neutral formaldehyde $\quad(0.4 \%$ final concentration $)$. Microphytoplankton samples were taken by horizontal trawls in surface waters (net of $30 \mu \mathrm{m}$ mesh) and preserved with neutral formaldehyde ( $4 \%$ final concentration). The qualitative analysis was performed under a phase contrast optical microscope.

A vertical trawling with a net of $200 \mu \mathrm{m}$ mesh and $50 \mathrm{~cm}$ mouth collected zooplankton samples. The organisms were preserved with neutral formaldehyde ( $4 \%$ final concentration). Water volumes passed through the net were estimated as described by Boltovskoy (1981). Subsamples were obtained using Motoda sampler (Omori \& Ikeda, 1984).

Diversity $\left(H^{\prime}\right)$ and evenness $\left(J^{\prime}\right)$ indices were computed according to Shannon-Weaver (1963) and Pielou (1966) considering only the identified organisms (at level of genera or species) of phytoplankton and zooplankton communities. Indices for phytoplankton were computed based on the sum of results obtained at the three different depths in each station. Zooplankton indices were computed based on Copepod counts.

Principal Component Analysis (PCA, sense Legendre \& Legendre, 1983) was applied to the physical (temperature, salinity), chemical (dissolved nutrients, oil and grease) and biological (total Chl- $a$, active Chl- $a$, BOD, suspended matter and phytoplankton density) data sets. Zooplankton data were not included in the analysis on account of the sampling methodology. Each descriptor set was transformed to normalized variables with zero mean 
and unit variance. The analysis was done using FITOPAC software (Shepard, 1994).

\section{Results}

Vertical distribution of the studied variables in transects A, B, C, and D are exhibited respectively in Figures 2, 3, 4 and 5.

On all transects, the water column showed a continuous thermal stratification without a defined thermocline. Temperatures varied from $25.20^{\circ} \mathrm{C}$ (surface) to $17.25^{\circ} \mathrm{C}$ (bottom waters), indicating the presence of $\mathrm{CW}$ in the upper layers and waters with high degree of mixture with SACW below $25 \mathrm{~m}$ depth. These assumptions are based on Aidar et al. (1993) that considered the $18^{\circ} \mathrm{C}$ isotherm as the limit for waters under SACW influence. Salinity ranged from 34.98 to 35.52 increasing downward. Dissolved nutrients exhibited increasing concentrations with depth due to the influence of the nutrient rich SACW in bottom layers. Nitrate was the main inorganic nitrogen form, varying from 0 to $3.2 \mu \mathrm{M}$ in $\mathrm{CW}$ domain and from 4.10 to 6.30 $\mu \mathrm{M}$ in SACW. Ammonium average values were 0.35 $( \pm 0.23) \mu \mathrm{M}$ in CW and $0.61( \pm 0.20) \mu \mathrm{M}$ in SACW domain. Total inorganic nitrogen $\left(\mathrm{TN}=\mathrm{NO}_{3}{ }^{-}+\right.$ $\mathrm{NH}_{4}^{+}+\mathrm{NO}_{2}^{-}$) exhibited higher values in transect $\mathrm{A}$, while in the superficial layers $(0-15 \mathrm{~m})$ of the transects $\mathrm{B}, \mathrm{C}$ and $\mathrm{D}$, concentrations remained below $1.0 \mu \mathrm{M}$. Phosphate showed similar distribution pattern in all transects with concentrations lower than $0.30 \mu \mathrm{M}$ above $10 \mathrm{~m}$ depth, increasing up to $0.83 \mu \mathrm{M}$ (maximum value) downwards. The silicate mean value in the upper layers was 1.84 $( \pm 0.81) \mu \mathrm{M}$ whereas on bottom waters this value was $4.42( \pm 0.52) \mu \mathrm{M}$. Higher silicate concentrations in upper layers were recorded in transect $D$. $N: P$ ratios showed low values $(0.95: 1$ to $12.29: 1)$ on all transects, even in bottom waters. Such results demonstrate that SSC waters are deficient in inorganic nitrogen forms.

Oil and grease (OG) were detected in all stations of the transect $\mathrm{A}$, where the highest level was obtained ( $6 \mathrm{mg} \mathrm{l}^{-1}$, St. 2, surface). Surface waters of stations $6,7,14,17,18$ and 19 also exhibited some contamination. BOD values were lower than $5 \mathrm{mg} \mathrm{l}^{-1}$ except for stations 2 and 15 $\left(6 \mathrm{mg} \mathrm{l}^{-1}\right)$ and station $16\left(14 \mathrm{mg} \mathrm{l}^{-1}\right)$. Phenol and sulfide were not detected in the sampling points.

$Z_{\text {eu }}$ was at approximately $12 \mathrm{~m}$ in transect $A$ and $11 \mathrm{~m}$ in transect $D$ (Table 1). The highest depths of $Z_{\mathrm{eu}}$ were recorded in the central stations of $\mathrm{B}$ and $\mathrm{C}$ transects (around $30 \mathrm{~m}$ ). A significant reduction was detected in stations 6,15 and 20 generally related to the higher total suspended matter (TSM) content in the water column. The TSM distribution exhibited high concentrations at mid waters close to the margins especially at the insular edge. This distribution seemed to be related to the current action in sediment suspension. TSM was comprised basically by inorganic material but the highest values were associated with the increase in the organic fraction (OSM) that contributed with more than $80 \%$ of the bulk, in such cases. This feature is clearly illustrated in the TSM and OSM distribution profiles in transects A to C (Figs 2 to 4 ).

Phytoplankton biomass $(0.16$ to $6.42 \mathrm{mg}$ Chl- $a \mathrm{~m}^{-3}$ ) was similar to the range obtained in other studies at SSC (Gianesella-Galvão et al., 1997; Gaeta et al., 1990) and in neighboring areas (Aidar et al., 1993; Zillmann, 1990). Chl- $a$ concentrations tended to increase downward and its spatial pattern showed a close relationship to the OSM in transects $A$ and D. A large proportion of total Chl- $a$ was in active state, specially in the mid deep layers, suggesting the cells were in a good physiological state or under a low zooplankton grazing pressure.

The $480 / 665 \mathrm{~nm}$ ratios computed from the absorbancies of pigment extracts in acetone $90 \%$ can be used as an index of nutritional state of phytoplankton cells (Heath et al., 1990). Results lower than 2.0 indicated good conditions in transect $\mathrm{A}$ and below $15 \mathrm{~m}$ depth in the other transects in general, while ratios higher than 2.4 indicated severe nutritional depletion. Comparing the profiles of inorganic nitrogen and 480/665 nm ratio (Figs 2 to 5), the relation between low nitrogen levels and phytoplankton cells under nutritional depletion can be clearly established.

Total phytoplankton density ranged from $11.210^{5}$ to $67.310^{5}$ cells $1^{-1}$, with the highest values observed close to the edges. Phytoflagellates were the most abundant group, comprising around $70 \%$ of the total number of organisms. Diatoms were the next most abundant group representing 22 to 27 $\%$ of the total phytoplankton observed (Fig. 6). At stations 11 (mid and bottom waters) and 7 (bottom) diatoms were the dominant group and they were as abundant as flagellates at the surface of stations 9 and 14, mid-water of stations 10,14 and 15 , and at station 6 (bottom).

Qualitatively, 53 phytoplanktonic taxa were identified: 43 diatoms, 8 dinoflagellates, 1 cyanobacteria (Anabaena sp) and 1 silicoflagellate (Dictyocha fibula). This excludes the phytoflagellate group and unidentified species. The most important diatom species were Leptocylindrus danicus, $L$. minimus, Dactyliosolen fragilissimus, Skeletonema costatum and Pseudo-nitzschia sp. Dinoflagellates were most abundant at station 2 and the more frequent genera were Cochlodinium, Gonyaulax, Gymnodinium, Prorocentrum and Protoperidinium. 


\section{Transect A}

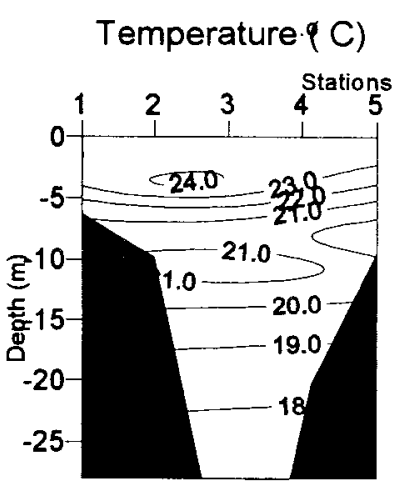

Inorganic Nitrogen $(\mu \mathrm{M})$

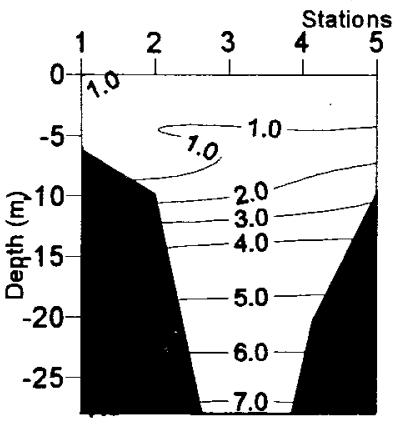

Oil and Grease (mg/l)

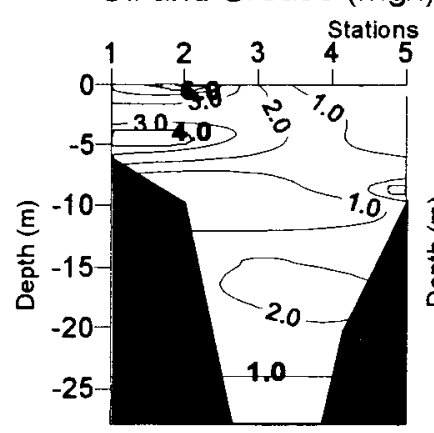

Total Chl-a $\left(\mathrm{mg} / \mathrm{m}^{3}\right)$

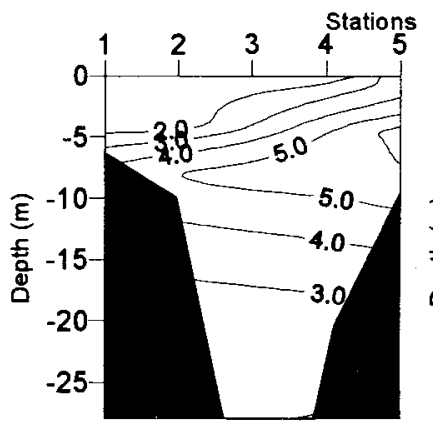

Salinity

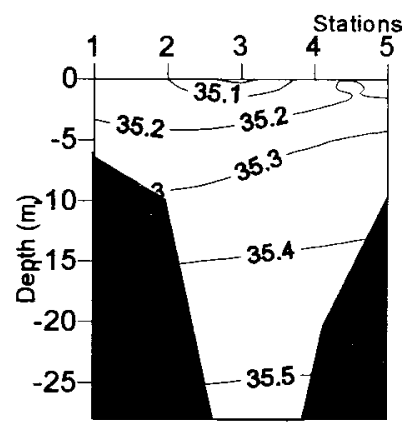

Phosphate $(\mu \mathrm{M})$

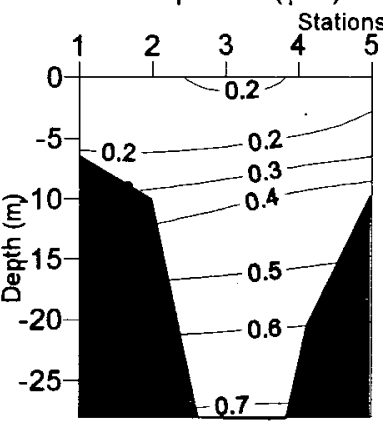

BOD $(\mathrm{mg} / \mathrm{l})$
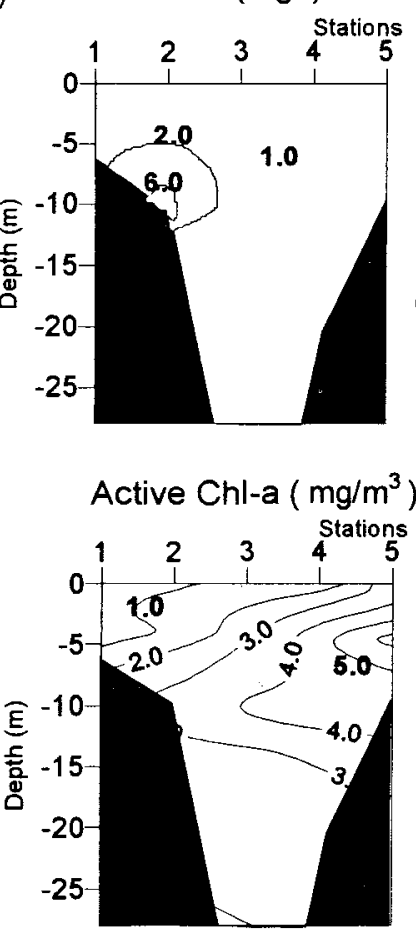
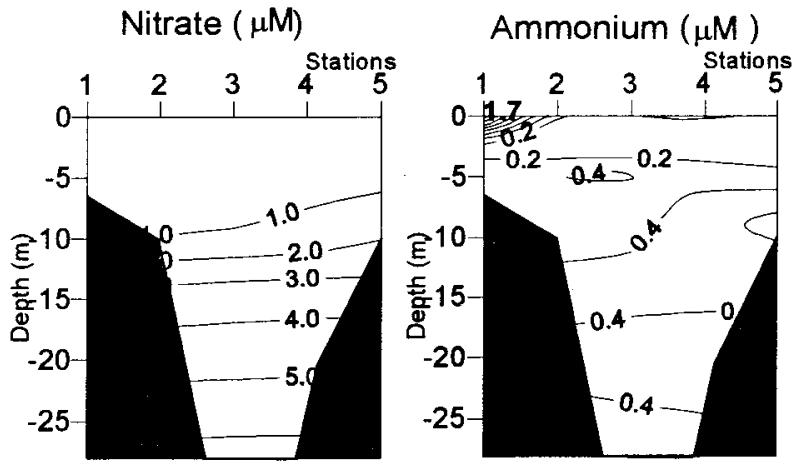

Silicate $(\mu \mathrm{M})$
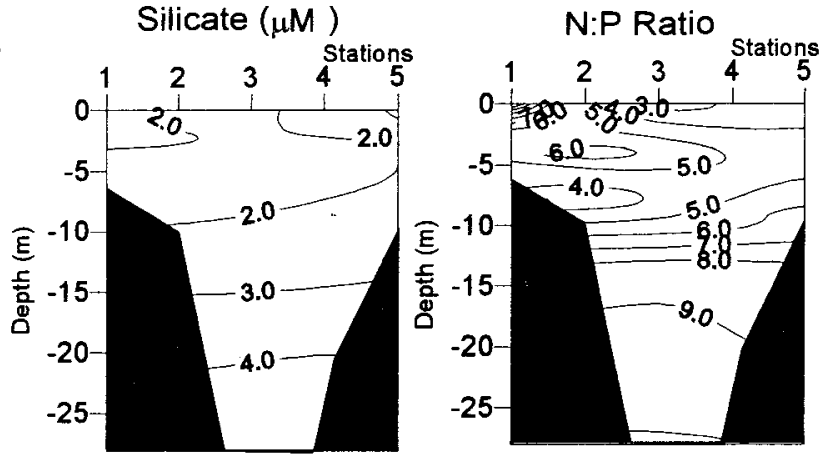

TSM (mg/l)
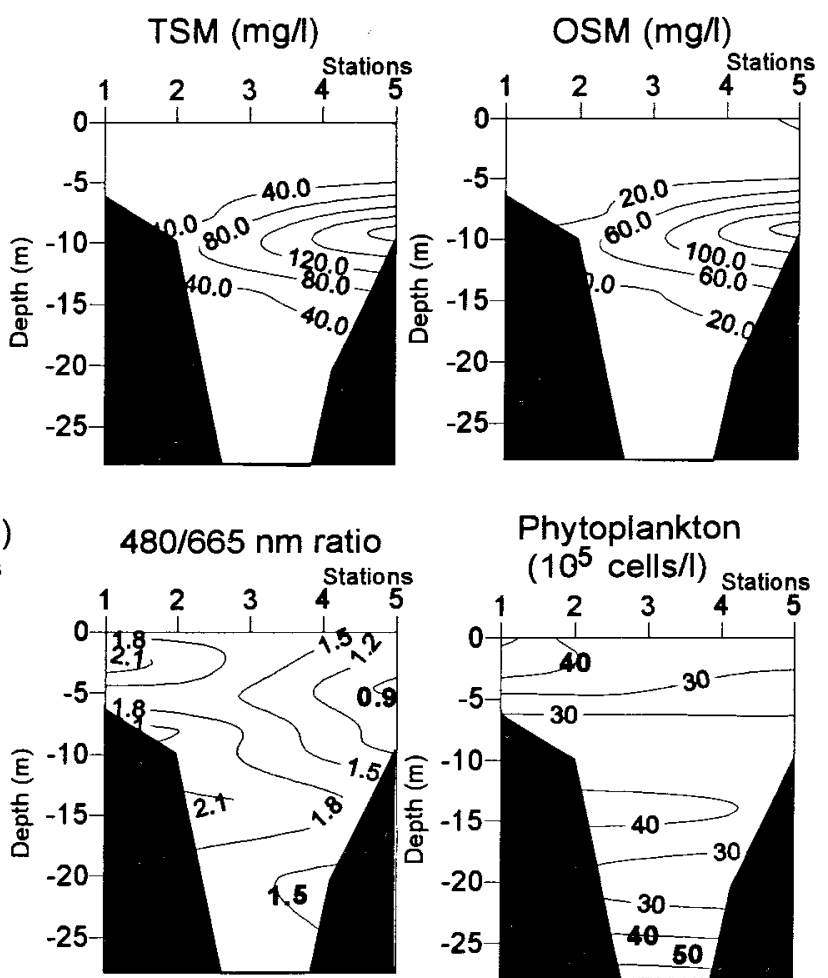

Phytoplankton

$\left(10^{5}\right.$ cells $\left./ l\right)$ Stations

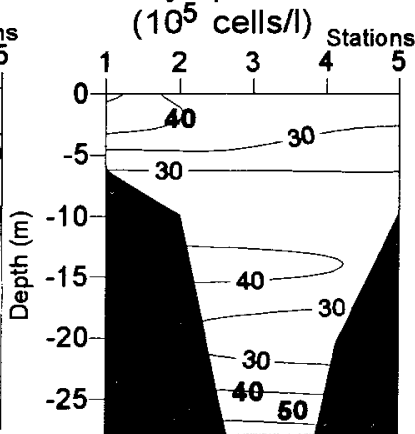

Fig. 2. Vertical distribution of the physical, chemical and biological variables along the transect $A$ (stations 1 to 5). 


\section{Transect B}
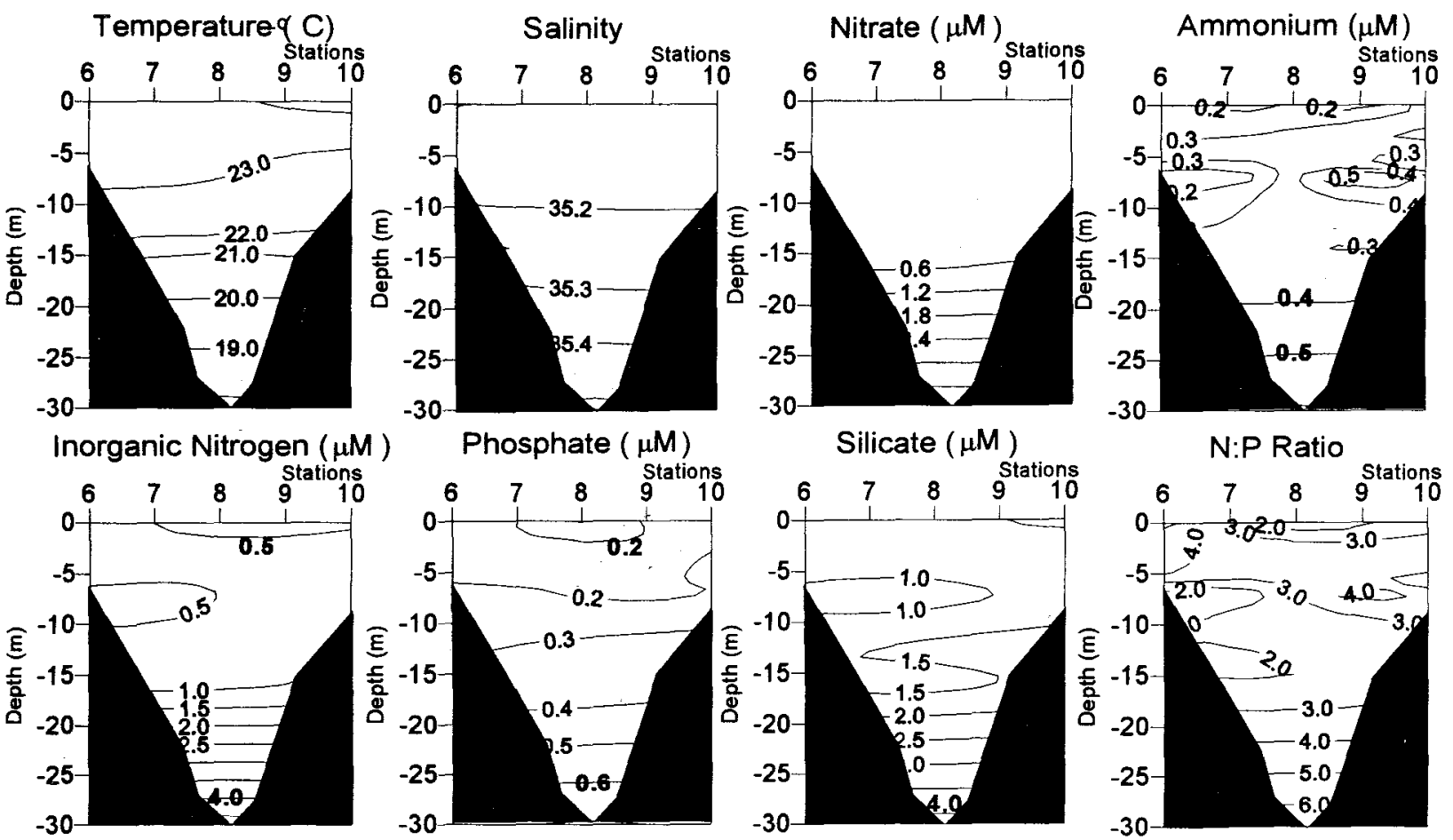

N:P Ratio
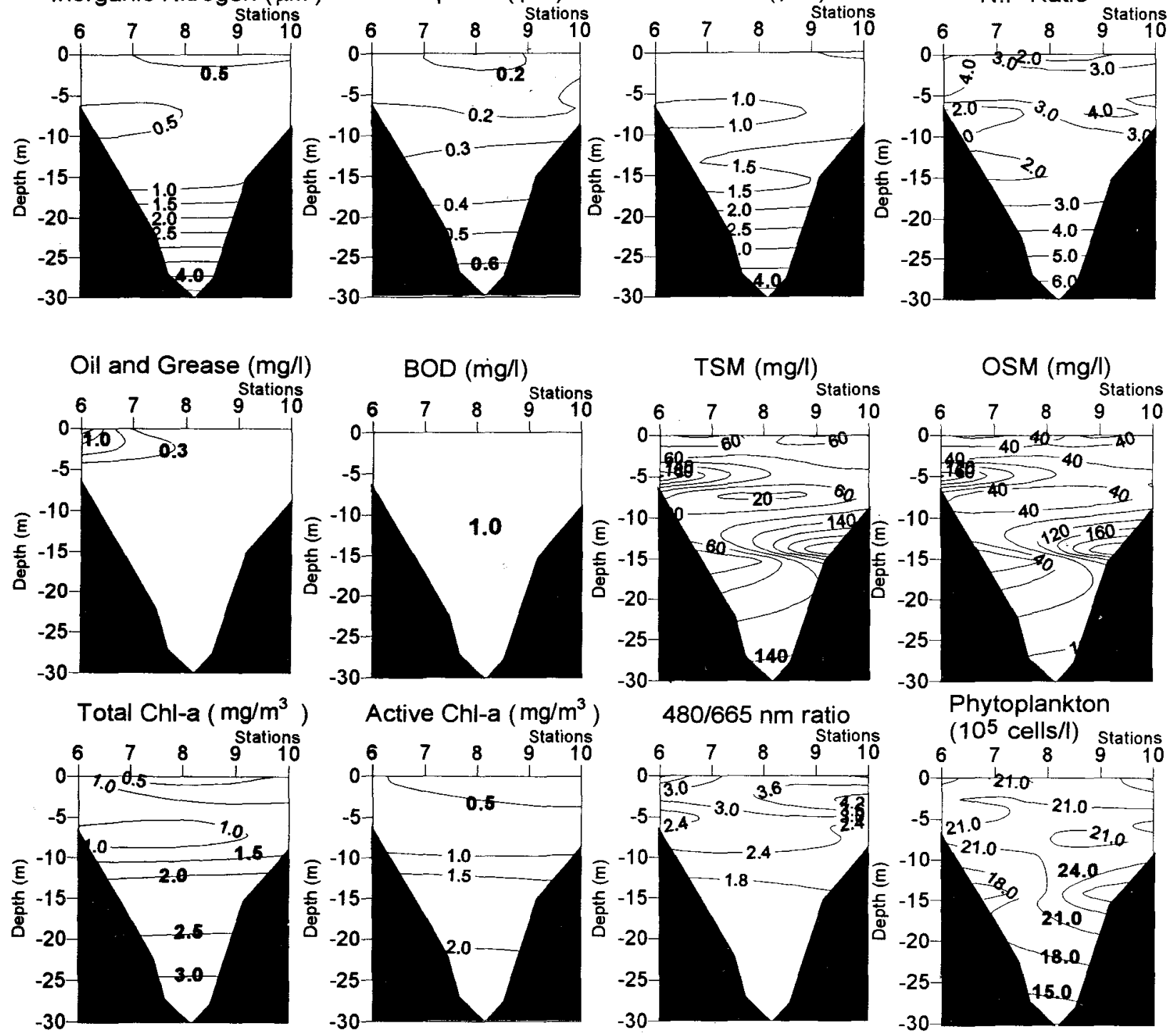

Fig. 3. Vertical distribution of the physical, chemical and biological variables along the transect B (stations 6 to 10 ). 


\section{Transect C}

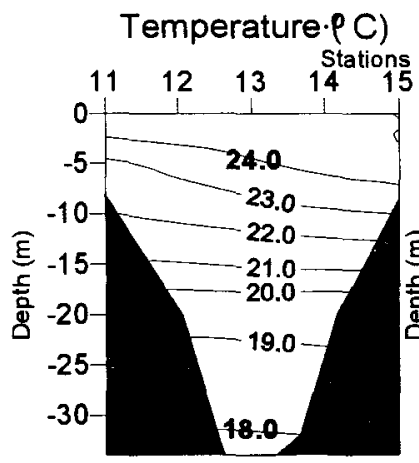

Inorganic Nitrogen $(\mu \mathrm{M})$
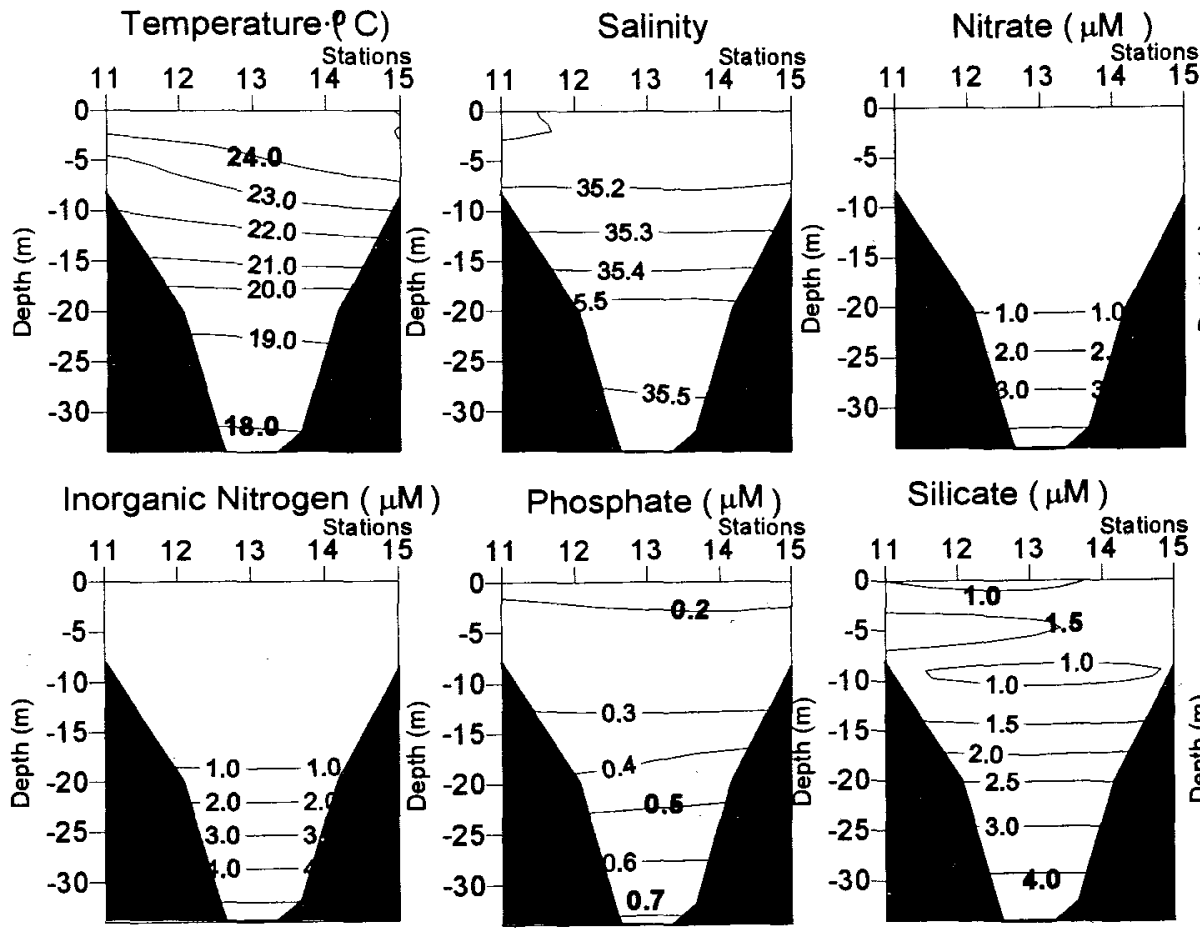

Silicate $(\mu \mathrm{M})$
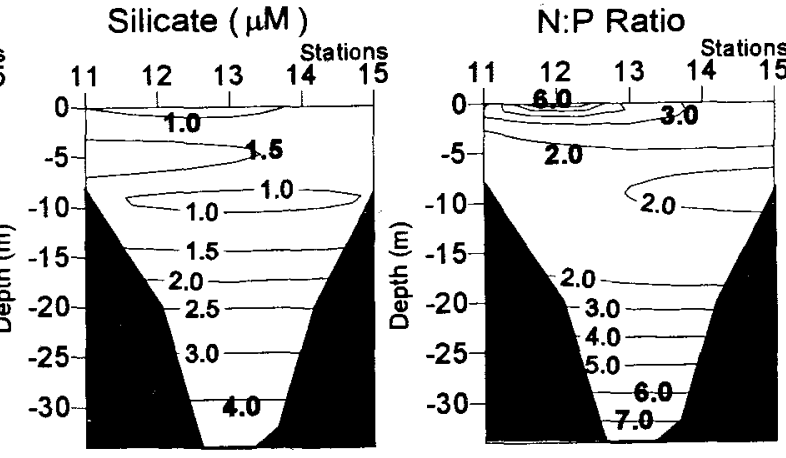

N:P Ratio

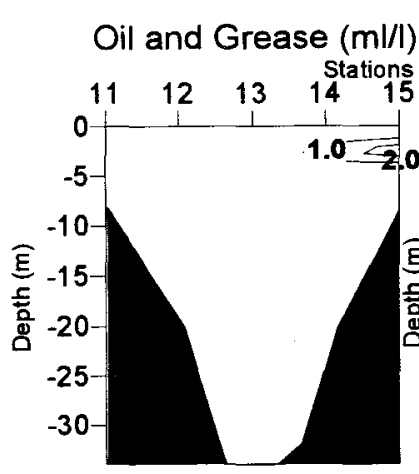

Total Chl-a $\left(\mathrm{mg} / \mathrm{m}^{3}\right)$

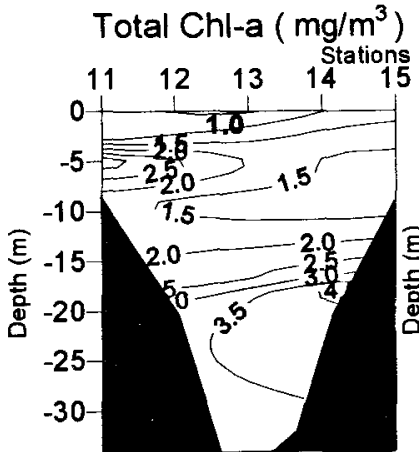

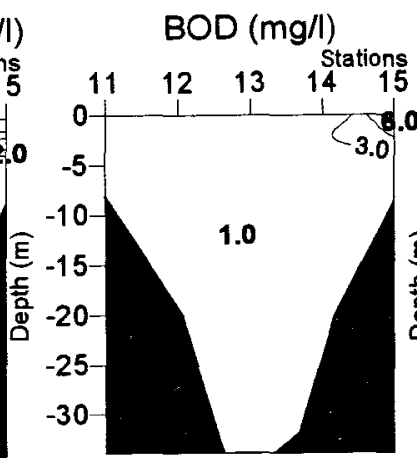

Active Chl-a $\left(\mathrm{mg} / \mathrm{m}^{3}\right)$

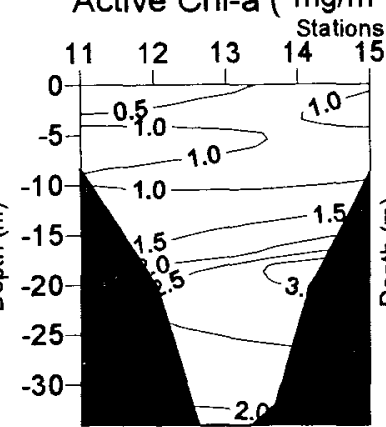

Ammonium ( $\mu \mathrm{M}$ )
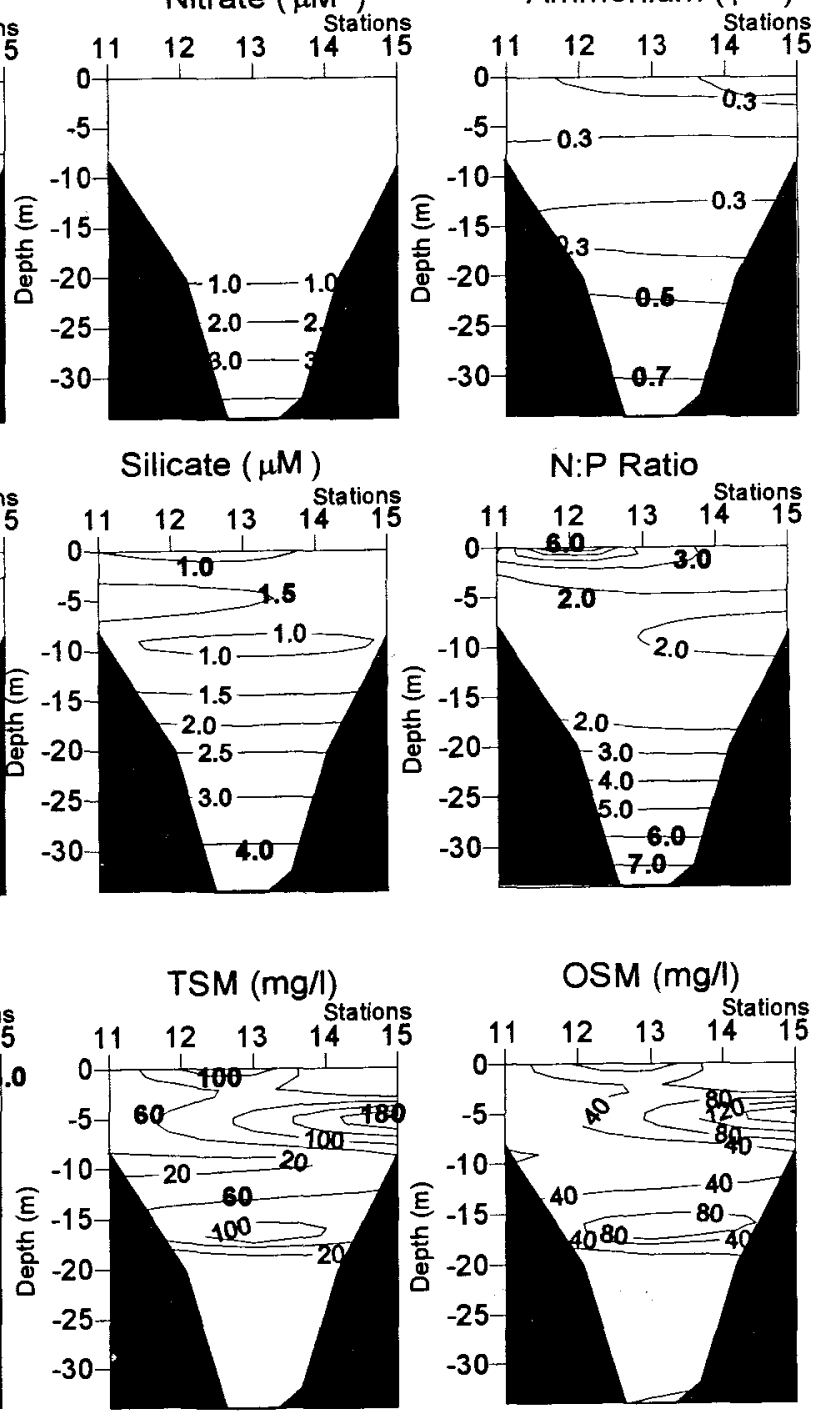

Phytoplankton (10 $\sigma^{5}$ cells/l) stations
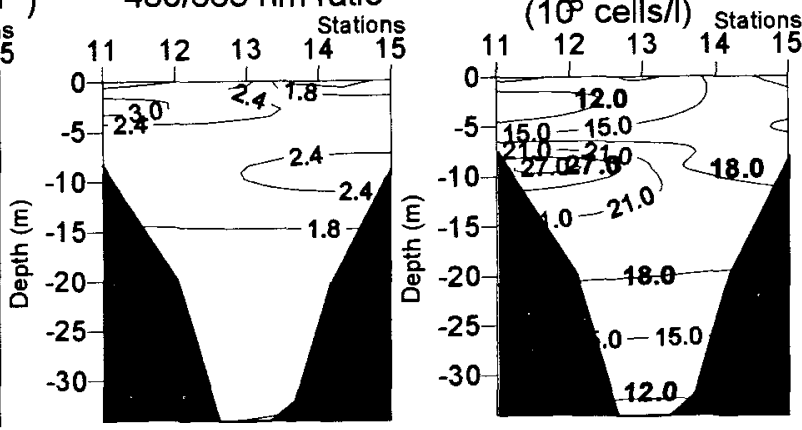

Fig. 4. Vertical distribution of the physical, chemical and biological variables along the transect $\mathrm{C}$ (stations 11 to 15 ). 


\section{Transect D}
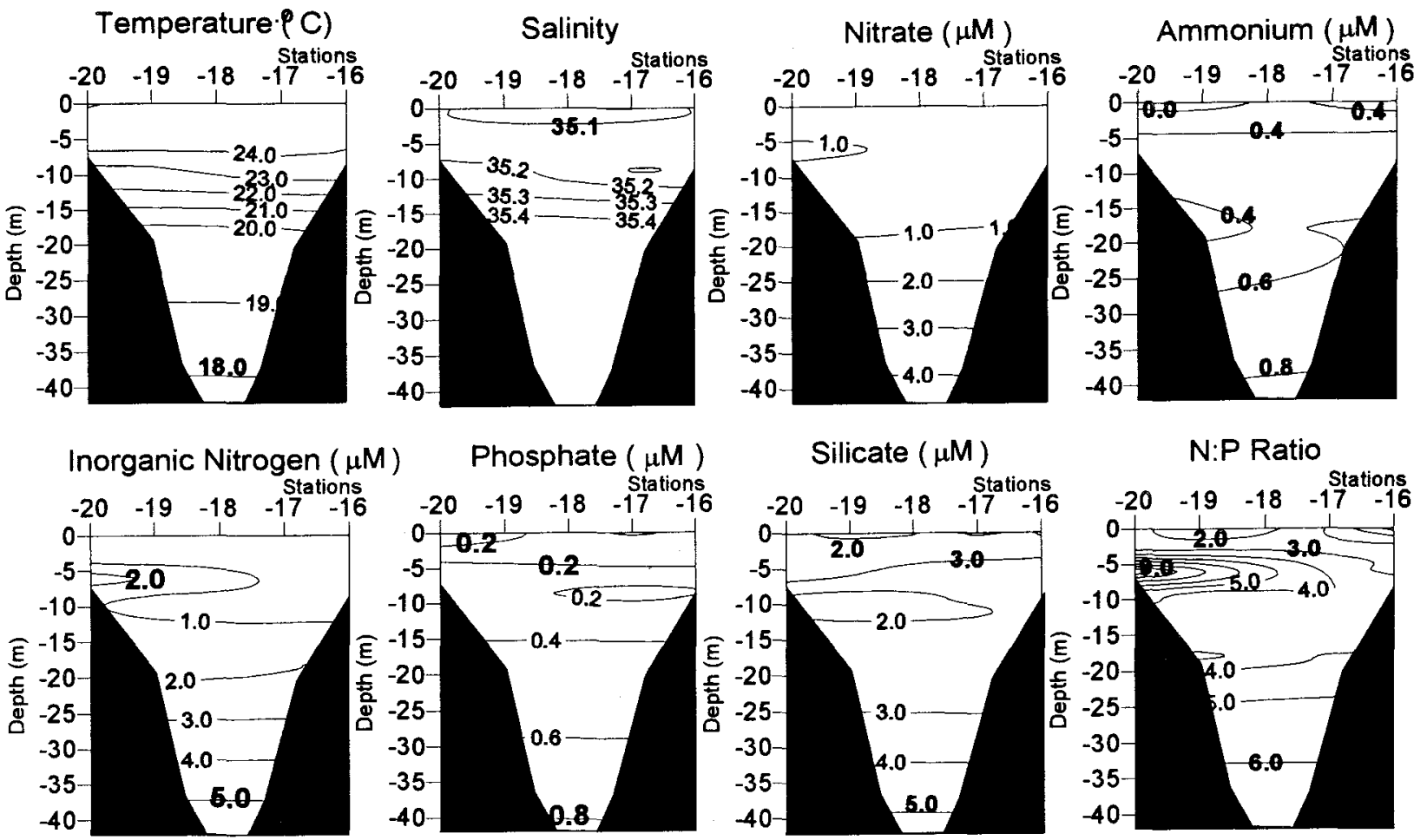

Phosphate ( $\mu \mathrm{M})$

Silicate $(\mu \mathrm{M})$

\section{N:P Ratio}
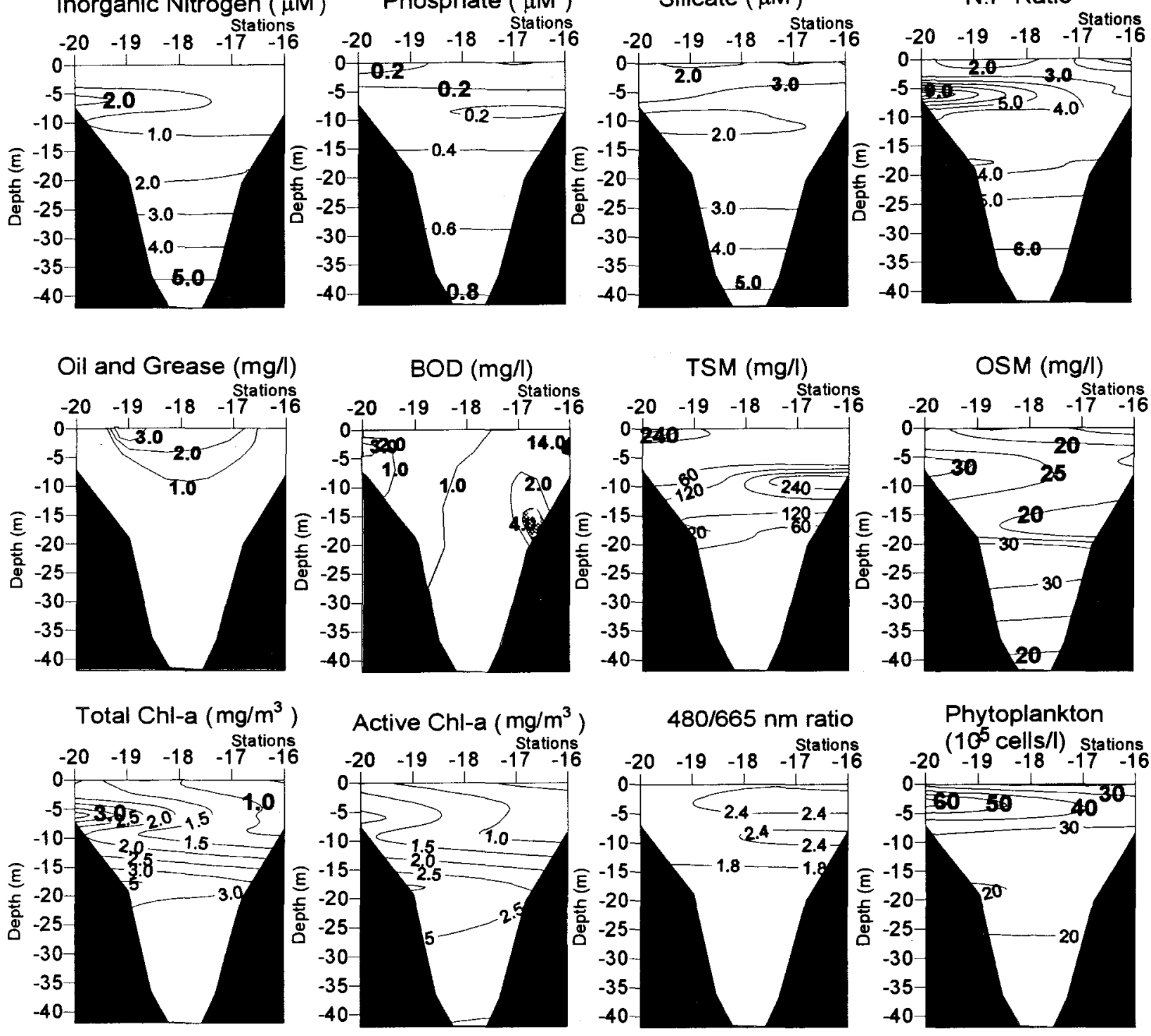

Fig. 5. Vertical distribution of the physical, chemical and biological variables along the transect D (stations 16 to 20 ). 

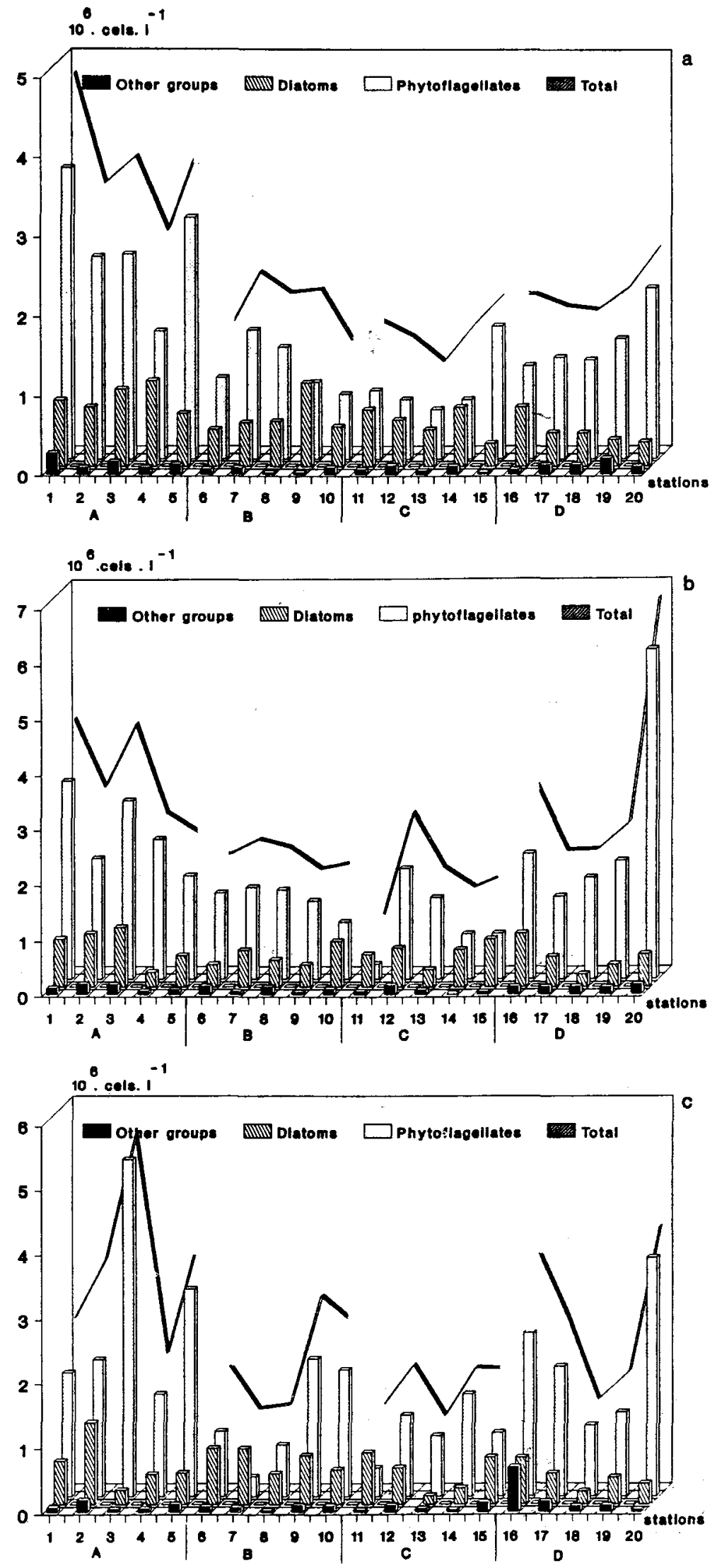

Fig. 6. Total phytoplankton density (cells $\mathrm{r}^{-1}$, represented by the line) and the contribution of the phytoflagellates, diatoms and other groups (represented by columns) in the 20 stations at: a) surface, b) mid water and c) bottom. 
Microphytoplankton (considered the fraction above $20 \mu \mathrm{m}$ ) showed a predominance of diatoms and few dinoflagellates. The most representative diatom genera were the same found for total phytoplankton, including Proboscia alata and Hemiaulus membranaceus. Among the dinoflagellates, Ceratium furca, C. fusus and Gonyaulax sp were the most frequent. The cyanobacteria Anabaena sp was scarcely represented.

Some diatom cells with deformed valves were observed, in about $20 \%$ of the samples, mainly the species Eucampia cornuta, Leptocylindrus danicus, Nitzschia sp, Proboscia alata and Rhizosolenia sp. These cells often seemed to be in poor physiological conditions (Fig. 7). Such samples came from stations located North of the DTCS and generally closer to the island side and in various water depths: surface (St. 4, 10 and 14), mid waters (St. 1, 2, 3, 7, 8, 10 and 11) and in bottom waters (St. 3, 7 and 9).

Phytoplankton ecological indices are presented in Table 2. Transect A showed the highest richness. Diversity $\left(\mathrm{H}^{\prime}\right)$ ranged from 1.53 to 3.53 and evenness $\left(J^{\prime}\right)$ ranged from 0.46 to 0.77 . The highest $\mathrm{H}^{\prime}$ and $\mathrm{J}$ ' values were found at the stations along the channel main axis (St. 3, 4, 7, 8, 13, 17 and 18). Actually, if other groups of organisms, such as small unidentified centric and pennate diatoms, coccolitophorids and phytoflagellates had been considered for the determination of these indices, values would certainly be improved.

Zooplankton density ranged from $210^{3}$ orgs $\mathrm{m}^{-3}$ (St. 1) to $27.6810^{3}$ orgs $\mathrm{m}^{-3}$ (St. 6). Low values were observed at transect $\mathrm{A}$ and in the stations located in the main channel (St. 8, 13, 18 and 19) where currents are stronger. High biomass values were found at stations $6,7,9,11,15,16$ and 20 . These stations are shallower and experience weak current action (Fig. 8).

Species composition was similar at all stations. Copepods were the dominant organisms at $80 \%$ of stations and comprised around $50 \%$ of the total zooplankton. Among the 25 identified taxa, Calanoida comprised $80 \%$ of copepod number at $60 \%$ of the stations. Paracalanus quasimodo was the dominant species followed by Temora stylifera, contributing both from $51 \%$ to $82 \%$ of the total copepods. An exception to this pattern was found at station 20 where Acartia lilljeborgi and Pseudodiaptomus acutus were the most important species, comprising together $68 \%$ of the total copepods. Paracalanus crassirostris represented $11 \%$ of the copepods at station 19 whereas Centropages velificatus $7 \%$ at station 17 . Less abundant species were Clausocalanus furcatus, Ctenocalanus vanus, Ctenocalanus sp,
Nannocalanus minor, Eucalanus pileatus, Calocalanus styliremis, Labidocera fluviatilis, Calanopia americana, in a decreasing importance order.
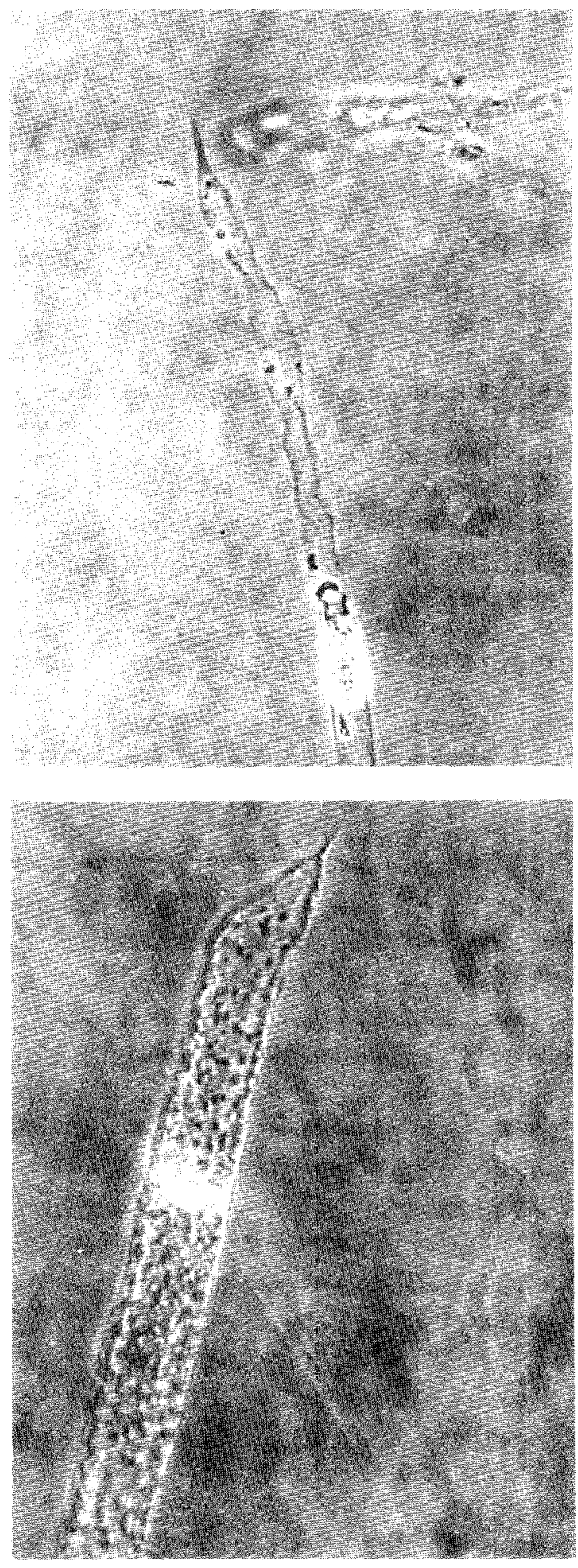

Fig. 7. Deformed valves observed in some Rhizosolenia sp cells. 
Table 2. Ecological indices computed for phytoplankton identified species at the 20 sampling stations in São Sebastião Channel (spring/91).

\begin{tabular}{|c|c|c|c|c|c|}
\hline STATION & $\begin{array}{l}\text { DENSITY } \\
\text { (cells / }^{-1} \text { ) }\end{array}$ & $\begin{array}{l}\text { RICHNESS } \\
\text { (S) }\end{array}$ & $\begin{array}{c}\text { DIVERSITY } \\
\text { (H') }\end{array}$ & $\begin{array}{l}\text { FMAX } \\
\left(\log _{2} S\right)\end{array}$ & $\begin{array}{c}\text { EVENNESS } \\
\left(J^{\prime}\right)\end{array}$ \\
\hline 1 & $2,267,265$ & 15 & 2.15 & 3.91 & 0.55 \\
\hline 2 & $2,987,985$ & 19 & 2.84 & 4.25 & 0.67 \\
\hline 3 & $2,319,818$ & 24 & 3.53 & 4.58 & 0.77 \\
\hline 4 & $1,816,815$ & 22 & 3.09 & 4.46 & 0.69 \\
\hline 5 & $1,726,725$ & 20 & 2.91 & 4.32 & 0.67 \\
\hline 6 & $1,696,695$ & 16 & 2.80 & 4.00 & 0.70 \\
\hline 7 & $2,064,563$ & 11 & 2.64 & 3.46 & 0.76 \\
\hline 8 & $1,524,023$ & 19 & 3.02 & 4.25 & 0.71 \\
\hline 9 & $2,192,190$ & 16 & 2.49 & 4.00 & 0.62 \\
\hline 10 & $1,861,860$ & 10 & 1.53 & 3.32 & 0.46 \\
\hline 11 & $2,102,100$ & 16 & 2.39 & 4.00 & 0.60 \\
\hline 12 & $1,861,860$ & 11 & 2.29 & 3.46 & $0.66^{\prime}$ \\
\hline 13 & 900,900 & 17 & 3.00 & 4.09 & 0.73 \\
\hline 14 & $1,629,128$ & 10 & 2.37 & 3.32 & 0.71 \\
\hline 15 & $1,861,860$ & 13 & 2.19 & 3.70 & 0.59 \\
\hline 16 & $2,417,415$ & 16 & 2.13 & 4.00 & 0.53 \\
\hline 17 & $1,433,933$ & 17 & 3.02 & 4.09 & 0.74 \\
\hline 18 & 840,84 & 17 & 3.06 & 4.09 & 0.75 \\
\hline 19 & $1,148,708$ & 12 & 2.41 & 3.58 & 0.67 \\
\hline 20 & $1,178,678$ & 9 & 2.40 & 3.17 & 0.76 \\
\hline
\end{tabular}

The second most abundant group was Cyclopoida ( 5 up to $30 \%$ of the total copepods), being Corycaeus giesbrechti the second most important species (in terms of number and frequency), reaching $30 \%$ of copepods at station 11 . Corycaeus amazonicus and Oithona hebes exhibited maximum contribution around $7 \%$ of the total copepods while Oithona plumifera and $O$. nana, Oncaea curta, $O$. media and $O$. venusta fulfilled around $2.5 \%$.

The Suborder Harpacticoida was less important in terms of number and frequency. Its greatest contribution was at stations 19 and 20 with $17 \%$ and $14 \%$ respectively, given mainly by Euterpina acutifrons. Microsetella norvegica and Clytemnestra rostrata were also present.

Cladocerans and appendicularians were more abundant and frequent along the channel main axis, performing a total of $14 \%$ (St. 10) up to $45 \%$ (St. 2) of total zooplankton. Echinoderms, chaetognaths, fish larvae and annelids were frequent but not abundant.

Ecological indices computed for Copepod are presented in Table 3 . Richness values ranged from 6 to 15. The lowest values were found next the DTCS (St. 11 to 13 and 20) while the highest richness was found at stations 2 to 5 and 15 . Diversity ranged from 1.15 to 2.47 . In a general way, low diversity was found at the stations close to the oil

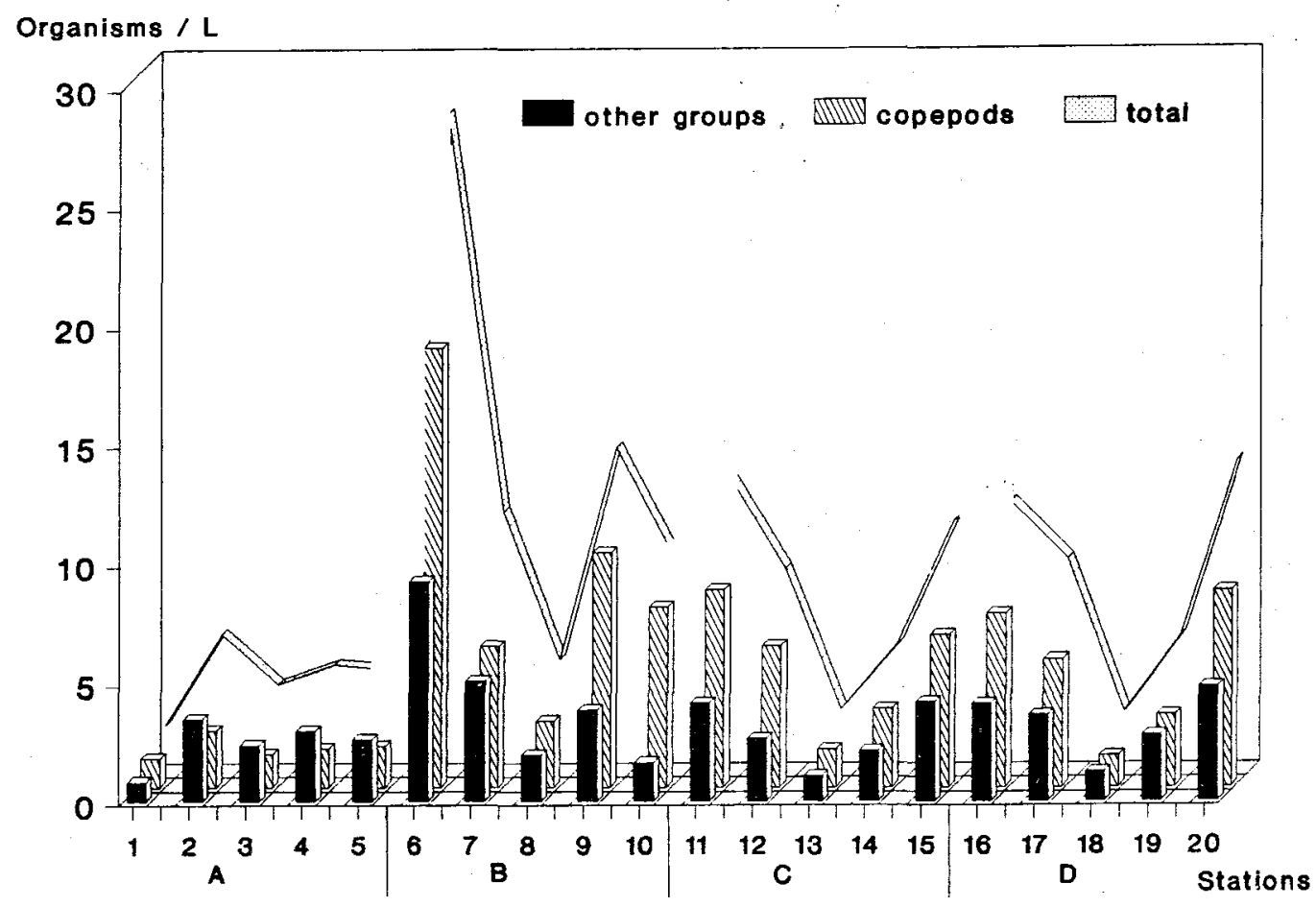

Fig. 8. Total zooplankton density (org $\mathrm{l}^{-1}$ ) and the contribution of the Copepods related to the other groups, in the 20 stations. 
Table 3. Ecological indices computed for the identified Copepoda at the 20 sampling stations in São Sebastião Channel (spring/91).

\begin{tabular}{|c|c|c|c|c|c|c|}
\hline STATION & $\begin{array}{c}\text { TOTAL } \\
\text { ZOOPLANKTON } \\
\text { (ORGS L }^{-1} \text { ) }\end{array}$ & $\begin{array}{l}\text { COPEPOD } \\
\text { DENSITY } \\
\text { (ORGS L') }\end{array}$ & $\begin{array}{c}\text { RICHNESS } \\
\text { (S) }\end{array}$ & $\begin{array}{c}\text { DIVERSITY } \\
\text { (H') }\end{array}$ & $\begin{array}{c}H^{\prime} M A X \\
\left(\log _{2} S\right)\end{array}$ & $\begin{array}{c}\text { EVENNESS } \\
\text { (J') }\end{array}$ \\
\hline 1 & 2,000 & 1,200 & 8 & 1.81 & 3.00 & 0.60 \\
\hline 2 & 5,824 & 2,368 & 12 & 2.43 & 3.58 & 0.68 \\
\hline 3 & 3,708 & 1,375 & 13 & 2.10 & 3.70 & 0.57 \\
\hline 4 & 4,549 & 1,610 & 15 & 2.18 & 3.91 & 0.56 \\
\hline 5 & 4,316 & 1,716 & 13 & 1.98 & 3.70 & 0.54 \\
\hline 6 & 27,680 & 18,440 & 11 & 1.45 & 3.46 & 0.42 \\
\hline 7 & 10,960 & 5,904 & 11 & 2.06 & 3.46 & 0.60 \\
\hline 8 & 4,750 & 2,792 & 11 & 1.64 & 3.46 & 0.47 \\
\hline 9 & 13,646 & 9,838 & 11 & 1.25 & 3.46 & 0.36 \\
\hline 10 & 9,180 & 7,560 & 9 & 1.15 & 3.17 & 0.36 \\
\hline 11 & 12,420 & 8,280 & 6 & 1.29 & 2.58 & 0.50 \\
\hline 12 & 8,544 & 5,909 & 9 & 1.46 & 3.17 & 0.46 \\
\hline 13 & 2,646 & 1,601 & 7 & 1.95 & 2.81 & 0.70 \\
\hline 14 & 5,387 & 3,286 & 11 & 2.11 & 3.46 & 0.61 \\
\hline 15 & 10,540 & 6,380 & 14 & 2.11 & 3.81 & 0.56 \\
\hline 16 & 11,361 & 7,281 & 10 & 1.93 & 3.32 & 0.58 \\
\hline 17 & 8,957 & 5,352 & 12 & 1.83 & 3.58 & 0.51 \\
\hline 18 & 2,560 & 1,322 & 12 & 1.31 & 3.58 & 0.37 \\
\hline 19 & 5,760 & 3,008 & 10 & 2.47 & 3.32 & 0.74 \\
\hline 20 & 13,038 & 8,238 & 9 & 2.02 & 3.17 & 0.64 \\
\hline
\end{tabular}

terminal (stations 6, 11 and 12), Northwards (St. 8, $9,10)$ and at station 18. Evenness ranged from 0.36 to 0.74 (St. 19) with the lowest values detected at the same stations of low diversity. In such cases, the dominant species was always Paracalamus quasimodo, sometimes followed by Corycaeus giesbrechti.

The three first components of PCA analysis explained $64 \%$ of total variance. The first component ( $42 \%$ explanation) was positively correlated to salinity, nutrients and chlorophyll (total and active) and negatively correlated to temperature and $480 / 665$ nm ratio (Fig. 9a). This component can be interpreted as the SACW influence on nutrient content over phytoplankton biomass development. Sampling points positively projected in axis I were related to bottom or mid water samples with high nutrient content, low temperature and low 480/665 $\mathrm{nm}$ ratio. Such points represent the best nutritional phytoplankton growth conditions in deeper stations, which show higher nutrient availability due to the mixture between $\mathrm{CW}$ and SACW. Points located in the negative side of axis I were generally related to surface and mid (and sometimes bottom) waters of shallower stations that are characterized by low nutrients, low chlorophyll- $a$ and high $480 / 665 \mathrm{~nm}$ ratio indicating nutritional deficiency.

Oil and grease concentrations and phytoplankton counts defined the second component (12.11\% explanation) at the positive side and total suspended matter (basically the organic fraction) at the negative side. This component can be interpreted as the current action revolving and transporting sediments in the channel against regions of low current intensity favoring the maintenance or the low dispersion of oil and grease spots.

The third component $(9.88 \%$ total variance explanation) is defined by phytoplankton biomass (number of cells and Chl- $a$ ) and oil and grease (Fig. 9b). In opposition to these variables are the $480 / 665$ $\mathrm{nm}$ ratios and ammonium. This feature indicates that higher phytoplankton biomass is related to good nutritional state represented by low $480 / 665 \mathrm{~nm}$ ratio. In this way, the third component seems to reflect the physiological status of the phytoplankton community. Sampling points located at the positive side represent phytoplankton in healthy condition while those in the negative one represent nutrient deficient cells.

\section{Discussion}

SSC waters are the result of the mixing among CW, SACW and TW, which are present in variable proportions over the continental shelf (Castro Filho, 1990; Miranda, 1982). The presence of water with the characteristics of SACW in the channel bottom layers is a common feature since this water mass reaches the channel through the deepest southern entrance when it floods the inner continental shelf. This phenomenon is more common during spring and summer due to the wind pattern (Castro Filho, op. cit.). 

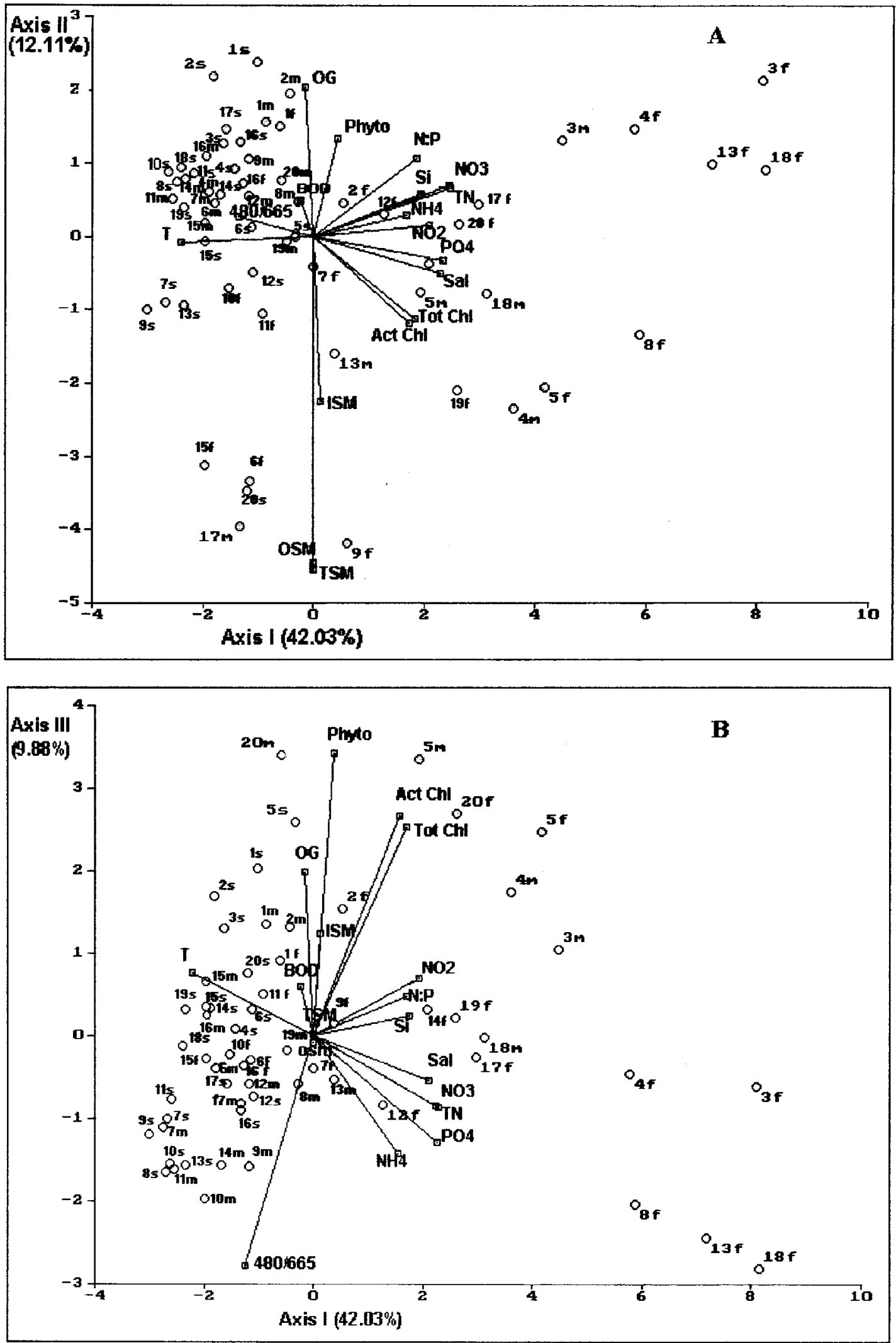

Fig. 9. Principal component analysis (PCA): representation of the covariables and samples in the factorial plane I-II (a), and in the factorial plane I-III (b). 
Despite the existence of a domestic sewage submarine outfall at Ponta do Araçá, South of the studied area (Lat. 23 $49^{\prime} 10^{\prime \prime} \mathrm{S}$ - Long. $45^{\circ} 24^{\prime} 14^{\prime \prime} \mathrm{W}$ ), there was no indication of eutrophication effects at the channel main stream, probably due to the strong currents, which allow a high dispersion (Soares, 1994). Nutrient concentrations were typical for waters under $\mathrm{CW}$ and SACW III (sense, Aidar et al., 1993) domain. Indeed, a great portion of the effluent is brought back to the Baía do Araçá (Lima, 1998) leading to a local eutrophication.

Considering that SSC is surrounded by beaches, its waters constitute a primary contact water that implies that oil, grease, sulfides and phenols should be virtually absent and BOD values should be lower than $5 \mathrm{mg} \mathrm{l}^{-1}$ (CONAMA, 1986). Results indicated oil and grease contamination in half of sampled station and BOD values above the acceptable limit in three points. Contamination was more frequent in surface and mid waters and especially in transects $\mathrm{A}$ and $\mathrm{D}$, not suggesting a direct relation to DTCS origin.

Rapport (1992) refers to several symptoms that should be considered in the assessment of an aquatic ecosystem. Alterations in biotic community structure favoring smaller forms; reduced species diversity, increased dominance by exotic or " $\mathrm{r}$ " selected species; shortened food chain length; increased disease prevalence and reduced population stability, are some examples.

Data obtained in the present work showed that the plankton community was similar in terms of biomass, density and diversity to oligo-mesotrophic environments of the Ubatuba region (Aidar et at., 1993; Zilmmann, 1990; Vega-Pérez, 1993) and the São Sebastião inner continental shelf (GianesellaGalvão et al., 1997). No significant differences in biomass and species composition from those reported by Gaeta et al. (1990) in the southern part of SSC were found.

Phytoplankton diversity $\left(\mathrm{H}^{\prime}\right)$ and evenness $(J)$ indices were high, especially at the stations located in the main channel. This can be ascribed to the variability of microenvironments, by the presence of $\mathrm{CW}$ and SACW along the water column. Lower values of $\mathrm{H}^{\prime}$ were observed at the margins dominated by $\mathrm{CW}$ and under low turbulence (Soares, 1994) which also favors low species diversity (Margalef, 1967).

Abnormal diatom cells were found at the stations located to the North of the oil terminal; at these same stations oil and grease were also detected, but it is insufficient to state that hydrocarbons or any associated substance could be a stress factor. However, no phytoplankton cells abnormalities were previously reported in this region. Although the preservation of the samples have been done according to the routine method used in phytoplankton studies and the small storage time, the possibility of those deformities be related to technical artifacts should not be excluded. Otherwise, Gianesella-Galvão (1982) observed morphological alterations in $S$. costatum and $L$. danicus in the Bay of Santos (SP), concomitant to the presence of mercury in the water. Hence, the phytoplankton morphology should be carefully examined in future monitoring in the area, considering "in vivo" observations of the cells in order to exclude the hypothesis of technical artifacts due to preservation of the samples and to identify any abnormality in the cells that could be caused by environmental contamination.

The observed spatial differences in zooplankton abundance did not show correlation with water masses. Copepod dominance in coastal waters is a common feature (Björnberg, 1981), as reported previously for the southern part of SSC by Gaeta et al. (1990), for São Sebastião inner continental shelf by Gianesella-Galvão et al. (1997) and for Ubatuba region by Vega-Pérez (1993). The most abundant species of copepods, cladocerans and appendicularians were the same reported by these authors.

In spite of the occurrence of colder waters at the deeper stations $(3,4,8,13$ and 18$)$, no typical cold waters species were found. Paracalanus quasimodo and Temora stylifera, the most frequent species, are susceptible to sewage pollution (EPOPEM, 1979). Indeed, significant decrease in their population occurred at station 20 , but the studied physical and chemical parameters could not explain such observation.

In the last decades, studies have demonstrated that different zooplanktonic species can change their feeding behavior as a function of the quality and quantity of the available food. There are many evidences that a great number of omnivorous groups can display several degrees of plasticity between carnivory and herbivory (Paffenhöfer, 1988; Kleppel, 1993). Considering the feeding behavior, the zooplankton community in the studied portion of SSC can be characterized as - (1) Omnivorous and primarily herbivorous: Paracalanus quasimodo, P. crassirostris, Temora stylifera, Acartia lilljborgi (Turner, 1984a, b; Turner, 1987; Gifford \& Dagg, 1988); (2) Omnivorous and primarily carnivorous: Eucalanus pileatus (Verity \& Paffenhöfer, 1996); (3) Omnivorous and primarily raptorial, feeding animals and large phytoplankton cells: Corycaeus giesbrechti, $C$. amazonicus and Centropages velificatus (Turner, op. cit.); (4) Filter 
feeders of pico and nanoplankton: cladocerans and appendicullarians (Alldredge, 1981, Bedo et al., 1993); (5) Carnivorous: Labidocera fluviatilis, Calanopia americana, and the chaetognaths, cnidarians and cirripedians (Paffenhöfer, 1988).

The low computed H' values seem to reflect the competition among copepods species since the greatest part of them have the same feeding behavior and the phytoplankton biomass is not abundant. The Copepod dominance in the majority of stations was indicated by low J' values.

Although some fluctuations in the structure of phytoplankton and zooplankton have been shown among the stations by the diversity and evenness indices, these parameters failed to indicate any discontinuity in the area that could be attributed to a stress factor. These fluctuations seem to be primarily related to the physical structure of the environment. In spite of the fact that the studied variables have pointed out a healthy ecosystem condition, morphological abnormalities found in some phytoplanktonic organisms may suggest the presence of stress factors. There may be a number of other factors, detectable or not, to be further considered in addition to those we have studied. As oil and grease were found in half of the sampled stations, these contaminants or any associated substance could be acting as stress agent.

Aidar et al. (submitted) tested the effects of the effluent to be discharged by DTCS into the channel, in Skeletonema costatum bioassays. They verified that this effluent might be extremely toxic, since the $\mathrm{EC}_{50}$ was obtained in the range from 0.18 to $0.30 \%$ of effluent concentration after 48 and $96 \mathrm{~h}$ respectively. Similar results were obtained in bioassays carried out by Souza \& Tommasi (1997) with the gastropod Costoanachis sertulariarum and by Phan et al. (1994) with the mysid Promysis atlantica. These studies showed clearly the high degree of injury that this effluent disposal is able to cause to the system if it will not be processed in a very controlled way, and also indicate the importance of continuous monitoring to evaluate possible alterations induced by this anomalous source.

The identification of stress conditions in the environment is crucial to the establishment of a proper system-management. Thus, the importance of developing studies on environmental diagnosis parallel to toxicological bioassays is undeniable

\section{Conclusions}

In spite of the single sampling period performed for the present study do not allow inferences on the natural variability of the system, the results here obtained, during a spring condition, indicated that the environment around the DTCS area did not differ from adjacent areas under lower anthropogenic pressure. The nutrient concentrations and phytoplankton biomass observed were in the range of coastal oligo-mesotrophic areas. The statistical analyses failed to indicate that oil and grease were impacting phytoplankton community. In addition, the examined indices of the biotic community structure showed no indication of stress, since the community displayed high diversity indices and zooplankton community comprised individuals of various feeding behaviors affording many trophic interactions.

\section{Acknowledgments}

We thank PETROBRÁS (Petróleo Brasileiro $\mathrm{S} / \mathrm{A}$ ) and FUNDESPA (Fundação de Estudos e Pesquisas Aquáticas) for the allowance of data publication. We also thank the valuable comments of the two anonymous referees.

\section{References}

Aidar, E.; Gaeta, S. A.; Gianesella-Galvão, S. M. F.; Kutner, M. B. B. \& Teixeira, C. 1993. Ecossistema costeiro subtropical: nutrientes dissolvidos, fitoplâncton e clorofila- $a$ e suas relações com as condições oceanográficas na região de Ubatuba, SP. Publção esp. Inst. oceanogr., S Paulo, (10):9-43.

Aidar, E.; Sigaud-Kutner, T. C. S.; Bícego, M. C.; Braga, E. S. \& Gianesella, S. M. F. (submit). Effects of the aqueous effluent from an oil maritime terminal on the Skeletonema costatum growth. Submitted to Rev. bras. oceanogr.

Alldredge, A. 1981. The impact of appendicularian grazing on natural food concentration in situ. Limnol. Oceanogr., 26(2):247-257.

Aminot, A. \& Chaussepied, M. 1983. Manuel des analyses chimiques en milieu marin. Brest, CNEXO. 395 p.

APHA - American Public Health Association. 1985. Standard methods for the examination of water and wastewater. $16^{\text {th }}$ ed. Washington, APHA. $1268 \mathrm{p}$. 
Bedo, A. W.; Acuña, J. L.; Robins, D. \& Harris, R. P. 1993. Grazing in the micron and the submicron particle size range: the case of Oikopleura dioica (Appendicularia). Bull. mar. Sci., 53(1):2-14.

Björnberg, T. K. S. 1981. Copepoda . In: Boltovskoy, D. ed. Atlas del zooplâncton del Atlántico sudoccidental y métodos de trabajo con el zooplancton marino. Mar del Plata, INIDEP. 936p.

Boltovskoy, D. 1981. Atlas del zooplâncton del Atlántico sudoccidental y métodos de trabajo con el zooplancton marino. Mar del Plata, INIDEP. $936 \mathrm{p}$.

Castro Filho, B. M. de 1990. Wind driven currents in the Channel of São Sebastião: winter, 1979. Bolm Inst. oceanogr., S Paulo, 38(2):111132.

Castro Filho, B. M. de; Miranda, L. B. de \& Miyao, S. Y. 1987. Condições hidrográficas na plataforma continental ao largo de Ubatuba: variações sazonais e em média escala. Bolm Inst. oceanogr., S Paulo, 35(2): 135-151.

CONAMA - Conselho Nacional do Meio Ambiente. 1986. Resolução no. 20 de 18/06/1986. In: Cabral, B. 1997. Direito Administrativo: tema água. Brasília, Senado Federal. 668p.

EPOPEM - Équipe de Pollution Pélagique de Marseille. 1979. Système planctonique et pollution urbaine. Un aspect des populations zooplanctoniques. Oceanol. Acta, 2(4):379-388.

Furtado, V. V. 1978. Contribuição ao estudo da sedimentação atual no Canal de São Sebastião. Tese de doutorado. Universidade de São Paulo, Instituto de Geociências. 2v.

Gaeta, S. A.; Abe, D. S.; Susini, S. M.; Lopes, R. M. \& Metzler, P. M. 1990. Produtividade primária, plâncton e covariáveis ambientais no Canal de São Sebastião durante o outono. Rev. Brasil. Biol., 50(4):963-974.

Gianesella-Galvão, S. M. F. 1982. Standing-stock and potential of phytoplankton production in the Bay of Santos, Brazil. Bolm Inst. oceanogr., S Paulo, 31(2):85-94.

Gianesella-Galvão, S. M. F.; Aidar, E.; Vega-Pérez, L. A. \& Saldanha-Corrêa, F. M. P. 1997.
Distribuição do plâncton na região costeira de São Sebastião. Relat. téc. inst. oceanogr., S Paulo, (41):5-14.

Gifford, D. J. \& Dagg, M. 1988. Feeding of the estuarine copepod Acartia tonsa Dana: carnivory vs. herbivory in natural microplankton assemblages. Bull. mar. Sci., 43(3):458-468.

Grasshoff, K.; Ehrardt, M. \& Kremling, K. 1983. Methods of seawater analysis. $2^{\text {nd }}$ ed. Weinheim, Verlag Chemie. $419 \mathrm{p}$.

Heath, M. R.; Richardson, K. \& Kiorboe, T. 1990. Optical assessment of phytoplankton nutrient depletion. J. Plankt. Res., 12(2):381-396.

Kleppel, G. S. 1993. On the diets of Calanoid copepods. Mar. Ecol. Prog. Ser., 99(1/2):183195.

Legendre, L. \& Legendre, P. 1983. Numerical ecology. Amsterdam, Elsevier. 419p.

Lima, G. M. S. B. 1998. Efeitos do efluente doméstico do emissário submarino de São Sebastião (SP), sobre o fitoplâncton marinho: estudos de campo e de laboratório. Tese de doutorado. Universidade de São Paulo, Instituto Oceanográfico. $160 \mathrm{p}$.

Lorenzen, C. J. 1967. Determination of chlorophyll and pheo-pigments: spectrophotometric equations. Limnol. Oceanogr., 12:343-346.

Margalef, R. 1967. Some concepts relative to the organization of plankton. Oceanogr. mar. Biol. a. Rev., 5:257-289.

Miranda, L. B. de 1982. Análise de massas de água da plataforma continental $e$ da região oceânica adjacente: Cabo de São Tomé (RJ) e Ilha de São Sebastião (SP). Tese de livre docência. Universidade de São Paulo, Instituto Oceanográfico. $123 \mathrm{p}$.

Omori, M. \& Ikeda, T. 1984. Methods in marine zooplankton ecology. New York, John Wiley. $332 \mathrm{p}$.

Paffenhöfer, G. A. 1988. Feeding rates and behavior of zooplankton. Bull. mar. Sci., 43(3):430-445.

Phan, V. N.; Gomes, V. \& Passos, M. J. A. C. R. 1994. Avaliação prévia da toxicidade de um efluente simulado derivado de petróleo sobre Promysis atlantica (Crustacea, Mysidacea). Bolm Inst. oceanogr., S Paulo, 42(1/2):129-141. 
Pielou, E. C. 1966. Species-diversity and patterndiversity in the study of ecological succession. $\mathrm{J}$. theor. Biol., 10(2):370-383.

Poole, H. H. \& Atkins, W. R. G. 1929. Photo-eletric measurements of submarine illumination throughout the year. J. mar. biol. Ass. U.K., 16:297-324.

Rapport, D. J. 1992. Evaluating ecosystem health. J. Aquat. Ecosyst. Health, 1:15-24.

Shannon, C. E. \& Weaver, W. 1963. The mathematical theory of communication. Urbana, University of Illinois Press. 117p.

Shepard, G. J. 1994. FITOPAC I - Manual de usuário. Universidade Estadual de Campinas, Departamento de Botânica. 88p.

Silva, L. S. 1995. Condições oceanográficas no Canal de São Sebastião e na região costeira adjacente: variações sazonais entre fevereiro de 1994 e março de 1995. Dissertação de mestrado. Universidade de São Paulo, Instituto Oceanográfico. 128p.

Soares, I. D. 1994. Um modelo numérico de dispersão oceânica: aplicações ao Canal de São Sebastião e adjacências. Dissertação de mestrado. Universidade de São Paulo, Instituto Oceanográfico. 126p.

Somerville, H. J.; Bennett, D.; Davenport, J. N.; Holt, M. S.; Lynes, A.; Mahieau, A.; McCourt, B.; Parker, J. G.; Stephenson, R. R.; Watkinson, R. J. \& Wilkinson, T. G. 1987. Environmental effect of produced water from North Sea oil operations. Mar. Pollut. Bull., 18(10):549-558.

Souza, E. C. P. M. \& Tommasi, L. R. 1997. Toxicidade do efluente derivado terminal marítimo da PETROBRÁS sobre o gastrópoda Costoanachis sertulariarum. Rev. bras. oceanogr., 45(1/2):95-99.

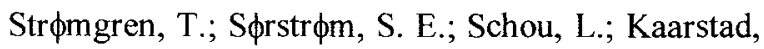
I.; Aunaas, T.; Brakstad, O. G. \& Johansen, $\phi$. 1995. Acute toxic effects of produced water in relation to chemical composition and dispersion. Mar. environ. Res., 40(2):147-169.
Turner, J. T. 1984a. Zooplankton feeding ecology: contents of fecal pellets of the copepods Eucalanus pileatus and Paracalanus quasimodo from continental shelf waters of the Gulf of Mexico. Mar. Ecol. Prog. Ser., 15(1/2):27-46.

Turner, J. T. 1984b. Zooplankton feeding ecology: contents of fecal pellets of the copepods Temora turbinata and $T$. stylifera from continental shelf and slope waters near the mouth of Mississipi River. Mar. Biol., 82(1):73-83.

Turner, J. T. 1987. Zooplankton feeding ecology: contents of fecal pellets of the copepod Centropages velificatus from waters near the mouth of Mississipi River. Biol. Bull., 173(2):377-386.

UNESCO. 1981. Background papers and supporting data on the Practical Salinity Scale 1978. UNESCO Tech. Pap. mar. Sci., 37:1-144.

Utermhöl, H. 1958. Zur Vervollkommnung der quantitativen Phytoplankton-Methodik. Mitt. int. Verein. theor. angew. Limnol., (9):1-38.

Vega-Pérez, L. A. 1993. Estudo do zooplâncton da região de Ubatuba, Estado de São Paulo. Publção esp. Inst. oceanogr., S Paulo, (10):65-84.

Verity, P. G. \& Paffenhöfer, G. A. 1996. On assessment of prey ingestion by copepods. J. Plankt. Res., 18(10):1767-1779.

Weber, R. R. \& Bícego, M. C. 1991. Survey of petroleum aromatic hydrocarbons in the São Sebastião Channel, SP, Brazil, November 1985 to August 1986. Bolm Inst. oceanogr., S Paulo, 39(2):117-121.

Zillmann, S. M. S. 1990. Distribuição sazonal do fitoplâncton na radial entre Ilha Anchieta e Itha da Vitória (Lat. $23^{\circ} 31^{\prime} \mathrm{s}$; Long. $45^{\circ} 06^{\prime} \mathrm{W}$ a Lat. $23^{\circ} 45^{\prime}$ S, Long. $45^{\circ} 01^{\prime} \mathrm{W}$ ) na região de Ubatuba, São Paulo. Dissertação de mestrado. Universidade de São Paulo, Instituto Oceanográfico. 2v.

(Manuscript received 19 August 1998; revised 15 December 1998; accepted 29 April 1999) 